\title{
Evolution of Neoarchaean supracrustal belts at the northern margin of the North Atlantic Craton, West Greenland
}

\author{
Julie A. Hollis, Marie Keiding, Bo Møller Stensgaard, Jeroen A.M. van G ool and A dam A. G arde
}

The Archaean N orth Atlantic Craton of West Greenland collided at C. $1.9 \mathrm{G}$ a with a lesser-known A rchaean craton to the north, to form the N agssugtogidian orogen. The Palaeoproterozoic metamorphic grade and strain intensity decrease northward through the orogen, allowing investigation of the reworked Archaean components in its northern part. Two Archaean supracrustal belts in this region the Ikamiut and Kangilinaaq belts - are investigated here using field mapping, aeromagnetic data, zircon geochronology, and geochemistry. Both belts comprise quartzo-feldspathic and pelitic metasedimentary rocks, amphibolite, and minor calc-silicate rocks, anorthosite and ultramafic rocks. Pb$\mathrm{Pb}$ and $\mathrm{U}-\mathrm{Pb}$ dating of detrital zircons and host orthogneisses suggest deposition at c. $2800 \mathrm{Ma}$ ( $\mathrm{K}$ angilinaaq belt) and after $2740 \mathrm{M} \mathrm{a}$ (I kamiut belt); both belts have zircons with $\mathrm{N}$ eoarchaean metamorphic rims. M etasedimentary rocks and orthogneisses at Ikamiut share similar steep REE signatures with strong LREE enrichment, consistent with local derivation of the sediment and deposition directly onto or proximal to the regional orthogneiss precursors. Zircon age data from Kangilinaaq indicate both local and distal sources for the sediment there. Geochemical data for Kangilinaaq amphibolites indicate bimodal, mixed felsic-mafic source rocks with island-arc basaltic affinities, consistent with a shelf or arc setting. Both belts experienced a similar tectono-metamorphic history involving $\mathrm{N}$ eoarchaean amphibolitefacies peak metamorphism at c. 2740-2700 Ma, possibly dueto continued emplace ment of tonalitic and granodioritic magmas. Nagssugtogidian lower amphibolite facies metamorphism at c. $1850 \mathrm{M}$ a was associated with development of the large scale $\mathrm{F}_{2}$ folds and shear zones that control the present outcrop pattern. The observed differences in the sources of the Kangilinaaq and I kamiut belts and their shared post-Archaean history suggest they were formed in different $\mathrm{N}$ eoarchaean environments proximal to and on a continental plate, and were amalgamated in a convergent margin setting shortly after their deposition.

Keywords: N orth Atlantic Craton, northern N agssugtogidian orogen, LA-ICP-M S, SIM S, zircon

J.A.H ., B.M .S., J.A.M .v.G. \& A.A.G., Geological Survey of Denmark and Greenland, Ø ster Voldgade 10,
D K-1350 Copenhagen K, D enmark. E-mail: jho@geus.dk
M .K., G eol ogical M useum, U niversity of C openhagen, Ø ster Voldgade 5-7, D K-1350 Copenhagen K, D enmark. 

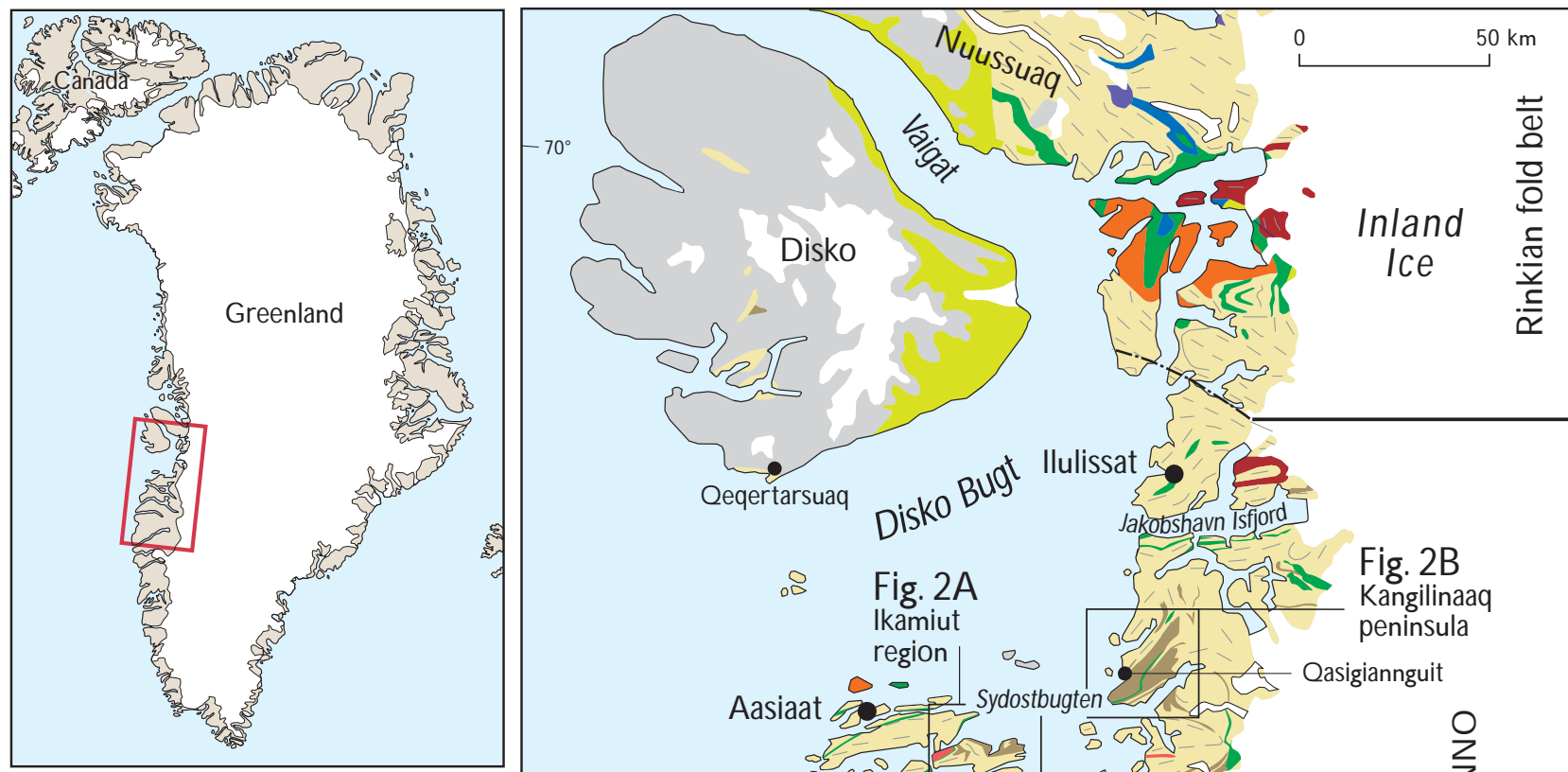

\section{Q uaternary}

Surficial deposits

\section{Cretaceous- Palaeo gene \\ $\begin{array}{ll}\square & \text { Basalt } \\ \square & \text { Sandstone }\end{array}$}

\section{Proterozoic}

$\diamond$ Sarfartoq carbonatite complex

Sisimiut charnockite

Arfersiorfik quartz diorite

Metasedimentary rocks

Archaean, variably reworked

Granodioritic and granitic gneiss

0 rthogneiss

Dioritic gneiss

Metasedimentary rocks

Amphibolite

(including Proterozoic components) Intermediate to basic intrusions

Boye Sø anorthosite complex

\section{Archaean, unreworked}

Granodioritic and granitic gneiss

Orthogneiss

Thrust

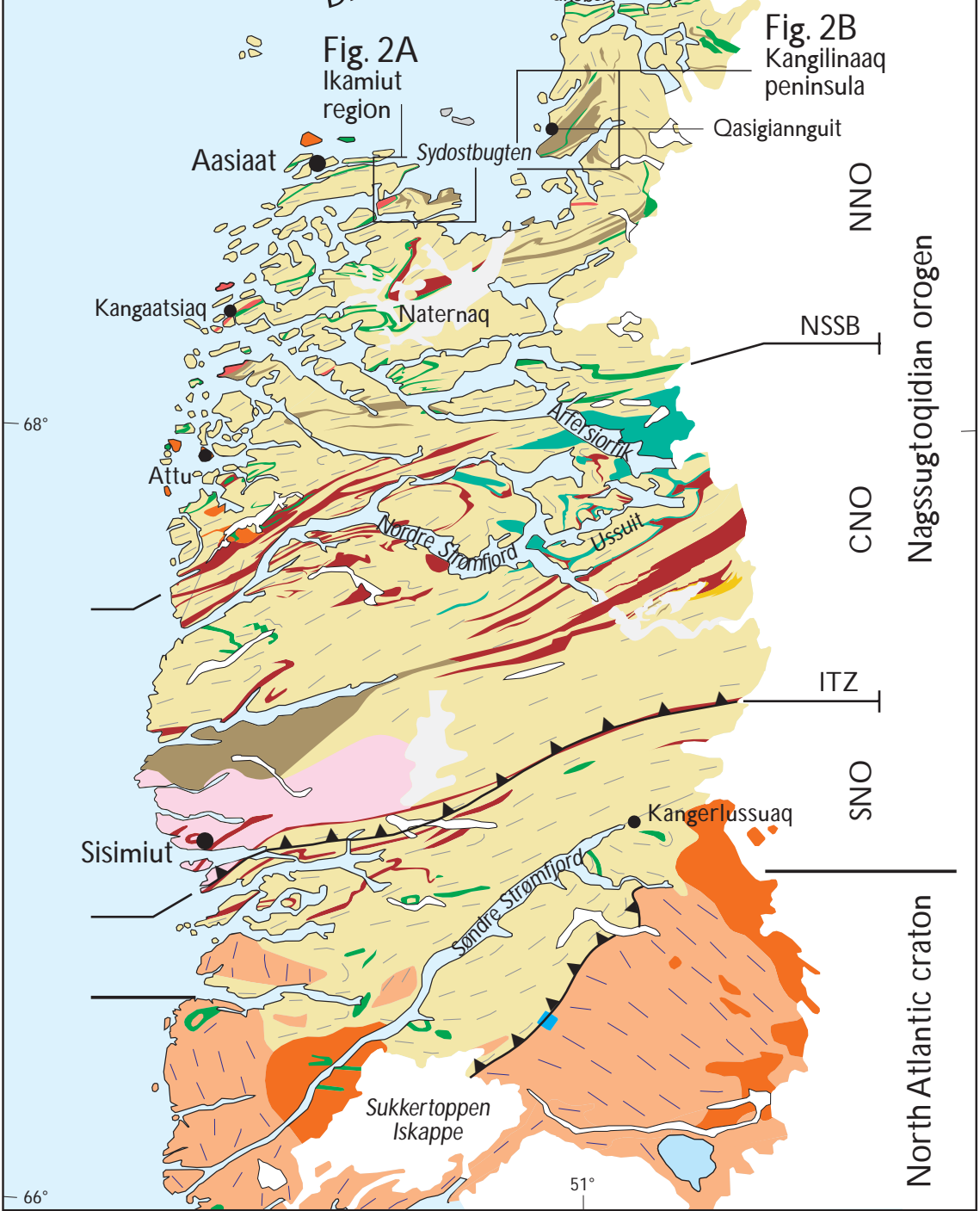

Fig. 1. Geological map of the $N$ agssugtogidian orogen, West Greenland, from van Gool et al. (2002b). Frames show locations of Figs 2 and 3. 
The Palaeoproterozoic N agssugtogidian orogen, central West Greenland, comprises Archaean and less abundant Proterozoic orthogneiss and metasedimentary rocks deformed and metamorphosed at c. $1850 \mathrm{M}$ a during collision of the North Atlantic Craton with a lesser-known, likewise Archaean craton to the north (Kalsbeek et al. 1987; Taylor \& Kalsbeek 1990; Kalsbeek \& Nutman 1996; Connelly et al. 2000; van Gool et al. 2002a). The orogen extends from Søndre Strømfjord in the south, northward to Disko Bugt and possibly farther into the largely contemporaneous Rinkian fold belt (Fig. 1). The metamorphic grade associated with orogenesis decreases from granulite facies in the collisional core (the central $N$ agssugtogidian orogen) to amphibolite facies in the southern foreland and the northern part of the orogen. Also the penetrative Palaeoproterozoic deformation diminishes toward the north in the northern Nagssugtogidian orogen ( N N O), and heterogeneous strain distribution may have been important in the preservation of pre-N agssugtoqidian, i.e. Archaean structural fabrics and metamorphic assemblages and textures (van Gool et al. 2002a; G arde et al. 2004; H ollis et al. 2004; Piazolo et al. 2004; $M$ azur et al. 2006, this volume). As a consequence of the northward decrease in thePalaeoproterozoic thermal overprint and deformation, the N N O providesan opportunity for investigation of the pre-N agssugtogidian history of its Archaean components. In particular, its supracrustal belts can provide valuable information on the tectonic environment(s) of their formation, their relationship to the plate-tectonic configuration, and whether different parts of the craton experienced the same or different Archaean histories.

$\mathrm{H}$ ere we investigate two supracrustal belts within the $\mathrm{N} \mathrm{NO}$ - the kilometre-widel kamiut and Kangilinaaq belts - that crop out on the western and eastern sides of Sydostbugten in southern Disko Bugt (Fig. 1). Parts of theN N 0 were mapped by the $\mathrm{G}$ eological Survey of Greenland in the 1960s for its 1:500 000 scale geological map series (N oe-N ygaard \& Ramberg 1961; H enderson 1969) and also by the $G$ eological Survey of $D$ enmark and $G$ reenland (GEUS) in 2000-2003 for the 1:100 000 scalegeological map series (see below). Henderson (1969) identified a complex map-scale fold structure that dominates the lkamiut peninsula and adjacent inland areas in the western Sydostbugten region, and also outlined many of the dominant lithologies and large structural elements in theK angilinaaq region.

In this paper we present geological, geochemical, geochronological and geophysical data from work carried out in the period 2000-2003 by GEUS mapping teams for the K angersuneq and Ikamiut 1:100 000 scale geological map sheets (van G ool 2005; Garde in press); part of this work is reported in more detail in Keiding (2004). Aeromagnetic data for the Sydostbugten region are correlated with major lithological and structural elements. G eochemical data from amphibolites in the $K$ angilinaaq region interpreted as deformed and metamorphosed basaltic volcanic rocks, and interlayered pelitic rocks, are used to determinethelikely depositional environment. Zircon $\mathrm{Pb}-\mathrm{Pb}$ and $\mathrm{U}-\mathrm{Pb}$ geochronology on granodioritic orthogneisses and a metasedimentary rock from the Ikamiut region is compared with existing data from the I kamiut and Kangilinaaq regions. Finally, theimplicationsfor regional $\mathrm{N}$ eoarchaean tectonics are discussed.

\section{Ikamiut belt and host rocks west of Sydostbugten}

Thel kamiut belt is a deformed, kilometre-thick sequence of biotite schists, with less abundant siliceous and pelitic rocks, amphibolite and minor ultramafic rocks. The belt forms a ten kilometre-scale antiform in the north-western part of Sydostbugten (Fig. 2A). It is everywhere in contact with C. $2830-2760 \mathrm{M}$ a old, tonalitic to granodioritic orthogneiss (Pb-Pb whole rock, Kalsbeek et al. 1987; $\mathrm{U}$-Pb zircon, Connelly \& M engel 2000 and this study), which dominates the region. The original nature of the contacts between the supracrustal belt and the regional orthogneiss is obscured by later ductile deformation (see also Ø stergaard et al. 2002). Rb-Sr data for 12 metasedimentary samples from this belt, near Ikamiut, gave an age of c. $1880 \mathrm{M}$ a for closure of the Rb-Sr system and a very high initial ${ }^{87} \mathrm{Sr}-{ }^{86} \mathrm{Sr}$ ratio of $\mathrm{c} .0 .712$, suggesting that these rocks were deposited at around $2.8 \mathrm{G}$ a and isotopically strongly reset during $\mathrm{N}$ agssugtogidian metamorphism (Kalsbeek \& Taylor 1999).

\section{Structure}

The structural pattern is dominated by kilometre-scale, closed, upright $\mathrm{F}_{2}$ folds folding an $\mathrm{S}_{1}$ foliation and associated with a moderate to intense, EN E-striking $\mathrm{S}_{2}$ foliation (Fig. 2A). Preservation of $S_{1}$ fabrics is found in areas of low $D_{2}$ strain, typically within the cores of large $F_{2}$ folds. $O$ utcrop-scale, parasitic $F_{2}$ folds associated with weak to moderately developed mineral lineations $\left(L_{2}\right)$ plunge at shallow angles to the WSW. In the eastern Ikamiut region, $\mathrm{L}_{2}$ lineations are shallow and, in some cases, plunge to the east. Some $F$, folds may be doubly plunging and/or refolded, consistent with localised outcrop-scale refolded 


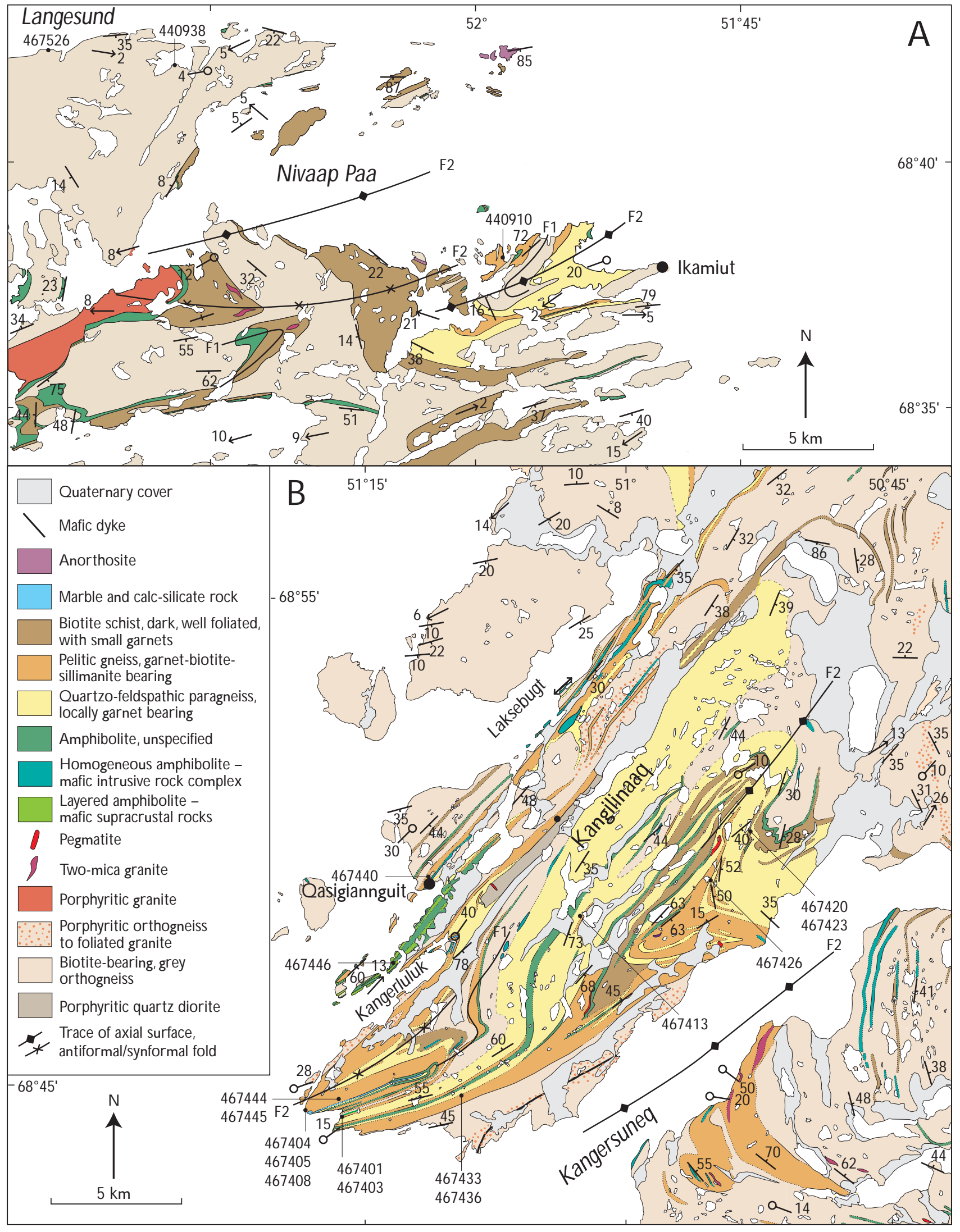

Fig. 2. Preliminary geological interpretation maps on (a) the Ikamiut region and (b) the Kangilinaaq peninsula, showing representative structural data, sample numbers and localities. For regional location see frames in Fig. 1. 
folds. The kilometre-scale, upright $F_{2}$ folds are probably parasitic on the major antiformal structure that dominates the outcrop pattern. Ten to hundred metre-scale, shallowlyW -plunging $\mathrm{F}_{2}$ folds of flat-lying $\mathrm{S}_{1}$ foliation are abundant in the tonalitic to granodioritic orthogneiss inland at the head of N ivaap Paa (Fig. 2A). These folds are difficult to trace for long distances along strike. The inland outcrop is relatively poor, and available outcrop suggests that some of the folds die out towards the west, apparently because of homogeneity and lack of ductility contrast within the orthogneiss.

\section{Lithologies, mineral assemblages and fabrics}

The tonalitic to granodioritic orthogneiss is a compositionally layered, medium-grained, pale pink and grey rock dominantly comprising plagioclase and quartz, with lesser K-feldspar and disseminated biotite. A medium- to coarse-grained gneissic layering $\left(S_{1}\right)$ is discontinuous on a scale of metres to tens of metres and commonly displays intrafolial isoclinal folds. The orthogneiss typically also holds a moderate, EN E-striking $S_{2}$ foliation that is a partially to completely transposed $S_{1}$ fabric, and a weakly to moderately developed, shallow $W$-plunging $L_{2}$ mineral lineation. M edium- to coarse-grained, centimetre-scalegranitic veins indicate variable $D_{2}$ strain: they form a layering that is typically transposed into $\mathrm{S}_{2}$, but in some cases they are slightly discordant.

Thesupracrustal sequenceisdominated by biotiteschists to gneissic rocks that typically comprise plagioclase, quartz, biotite, and rarely garnet. Interlayered with these rocks occur local, more mica-rich and aluminous layers up to $20 \mathrm{~m}$ thick, which commonly display a schistose $\mathrm{S}_{1}$ fabric. These rocks typically comprise biotite, plagioclase, quartz, muscovite, sillimanite, and garnet, with accessory tourmaline. Locally, in the most micaceous parts, a $D_{2}$ crenulation of $\mathrm{S}_{1}$ biotite, plagioclase and quartz \pm sillimanite is developed, with axial planes parallel to thedominant regional $\mathrm{S}_{2}$ gneissosity of the tonalitic-granodioritic orthogneiss host, and fine-grained biotite and muscovite along the crenulations. Aggregates of fine-grained sillimanite and biotite in biotiterich schists form blocky, centimetre-scale patches interpreted as pseudomorphs after andalusite. This suggests that the $\mathrm{S}_{1}$ fabrics and assemblages were formed at low-pressure $(<3.85 \mathrm{kbar})$, lower amphibolite facies metamorphic conditions, followed by increasing temperature (and possibly also pressure) into sillimanite-grade conditions.

A distinct unit of siliceous paragneiss, locally garnetbearing, is al so volumetrically important. It is distinguished from the biotite schist/gneiss by its more quartz-rich and mica-poor composition. It is often difficult to distinguish this lithology from the tonalitic to granodioritic orthogneiss, particularly in inland areas where outcrop is poor.

Amphibolitelayers, which are 10-50 m thick and laterally discontinuous on a kilometrescale, areassociated with the metasedimentary sequence. They commonly occur at or near boundaries between the metasedimentary rocks and orthogneiss. The amphibolites are medium grained and comprisehornblendewith lesser plagioclaseand quartz, and locally clinopyroxene \pm garnet. In some cases they show distinct mafic-felsic layering, and they commonly contain thin $(0.5-5 \mathrm{~cm})$, discontinuous felsic layers.

A few isolated occurrences of intensely deformed anorthosite occur at tectonised boundaries between the tonalitic to granodioritic orthogneiss and metasedimentary rocks. The largest occurrence is in the northern island group of $\mathrm{N}$ ivaap Paa (Fig. 2A). The anorthositic rock is coarse grained and 'zebra-striped', and consists of hornblende and calcic plagioclase with a variably developed foliation and an intense linear fabric. The mafic parts are commonly boudinaged within the more felsic component.

An extensive body of medium- to coarse-grained granite is located within the hinge zone of the large antiformal structure along the southern coast of N ivaap Paa. The granite is porphyritic and whiteto red in colour, and holds a weak gneissosefabric. I ts northern contact with the regional orthogneiss is tectonised and possibly tectonically repeated. The relatively undeformed nature of the granite suggests it intruded into the orthogneiss after formation of the regional gneissose fabric $\left(\mathrm{S}_{2}\right)$. T he granite contains thin lenses and layers of medium-grained amphibolite, and is bounded to the south by a layer of amphibolite 50-400 $m$ thick, the outcrop of which defines a tight synformal fold closure (Fig. 2A).

\section{Kangilinaaq belt and host orthogneiss east of Sydostbugten}

The Kangilinaaq peninsula (Fig. 2B) is dominated by a kilometre-scale synformal structure comprising a series of $\mathrm{NE}$-trending, upright, isoclinal $\mathrm{F}_{1}$ and $\mathrm{F}_{2}$ folds that repeat a thick supracrustal sequence. The most common lithologies are quartzo-feldspathic and pelitic metasedimentary rocks, with lesser amphibolite and subordinate marble and calc-silicate rocks. An equivalent supracrustal sequence is found south of Kangersuneq fjord, on the southern limb of an antiformal fold running through the fjord. A lithologically distinct unit of amphibolite and associated metasedimentary rocks runs through the town 
of Q asigiannguit in the west of the peninsula. For ease of reference this unit is named the $\mathrm{Q}$ asigiannguit amphibolite in the following. It is separated from the main supracrustal sequence by $200-500 \mathrm{~m}$ of high-strain Archaean orthogneiss. The significance of this high-strain zone in terms of the original supracrustal stratigraphy is uncertain, and thus the $Q$ asigiannguit amphibolite may or may not be part of an originally continuous supracrustal series on the Kangilinaaq peninsula. For descriptive reasons the two supracrustal sequences are collectively termed the Kangilinaaq belt in the following.

Pelitic rocks from the main supracrustal sequence contain Archaean detrital zircon populations in the range 2820-2760 M a, with a minimum depositional age constrained by an intrusive two-mica granite at $2723 \pm 15$ $\mathrm{M} \mathrm{a}$ (T hrane \& Connelly 2006, this volume). M etamorphic zircon growth occurred at $1920-1820 \mathrm{M}$ a in various rocks (Keiding 2004; Thrane \& Connelly 2006, this volume). Age data are addressed in more detail in the discussion.

\section{Structure}

The structural pattern is dominated by large, tight to isoclinal folds. Especially along the south-eastern side of the peninsula, the quartzo-feldspathic and pelitic rocks are intensely folded into upright folds on scalesfrom decimetres to tens of metres with shallowly N E-plunging fold axes. O Ider, isoclinal, often intrafolial folds indicate that the upright folds are at least second-generation $\left(F_{2}\right)$. A shear zone containing mylonitic orthogneiss bounds the supracrustal rocks to the south-east. It can be traced from the south-western part of the peninsula to half-way up Kangersuneq fjord, where it meets the water (Fig. 2B). Kinematic indicators and a lineation suggesting sinistral/ top to the west movement are poorly developed in the shear zone. The continuation of the shear zone may be found in a poorly developed, but continuous SE-trending shear zone south of $K$ angersuneq fjord, marked by a sliver of metasedimentary rocks. North-west of the supracrustal sequence, no similar shear zone was found, although some smaller zones of high strain were recognised.

\section{Lithologies, mineral assemblages and fabrics}

The predominant regional lithologies are layered, grey tonalitic to granodioritic orthogneisses interleaved with supracrustal rocks. Theorthogneisses contain variable proportions of plagioclase, quartz and biotite, with minor K- feldspar and hornblende. Compositional layering of orthogneiss with thin amphibolitelayersinterpreted as highly attenuated enclaves, give the rocks a layered appearance. The orthogneisses are intersected by concordant to slightly discordant, medium- to coarse-grained, centimetre- to half metre-scale granitic veins interpreted as derived from local melts. The orthogneisses show intrusive contactsinto part of the supracrustal sequence (see below), although it is not certain that this relationship applies to all of the supracrustal rocks on the peninsula. The gneissic fabric of orthogneiss in the core of the peninsulaislocally disturbed by pods and sweats of partial melt, which can contain millimetre-sized garnets. Garnet formation in theorthogneiss is restricted to the core of the peninsula, a region of abundant metasedimentary rocks. The garnet formation may be the product of contamination during partial melting of the metasedimentary rocks, either during intrusion of the precursors to the orthogneiss, or during metamorphism.

Variably deformed quartz diorite occurs in two localities. Typically it has tectonised contacts with the supracrustal rocks, but east of $\mathrm{Q}$ asigiannguit it has intrusive contacts to the latter and has yielded a U -Pb zircon emplacement age of $2801 \pm 34 \mathrm{M}$ a (T hrane \& Connelly 2006, this volume).

The main supracrustal sequence is dominated by medium-grained, quartzo-feldspathic metasedimentary rocks that commonly contain garnet. W here garnet is absent in these rocks, they are difficult to distinguish from the orthogneisses. The quartzo-fel dspathic paragneiss alternates on metre to 100 metre-scale with pelitic rocks, amphibolite and rare calc-silicate rocks. The pelitic rock comprises quartz, plagioclase, biotite, garnet, and sillimanite. Locally, it has a large component of granitic partial melt, commonly occurring in boudinaged lenses, indicative of upper amphibolite facies metamorphic conditions. Amphibolites are commonly dark and subtly layered, fine to medium grained and few metres to $50 \mathrm{~m}$ wide. Remnants of deformed pillows are locally present. In the eastern part of the sequence isolated lenses of metamorphosed ultramafic rocks occur in a few locations, commonly within amphibolites. They comprise predominantly amphibole and orthopyroxene, with or without clinopyroxene, olivine, phlogopite, and serpentinite. M inor calc-silicaterocks are layered, with variable grain size, and comprise calcite, phlogopite, quartz, tremolite and locally actinolite. Pelitic rocks in this sequence are commonly coarse grained and comprisequartz, biotite, garnet, plagioclase, and sillimanite. Large lumps of fibrous sillimanite (up to $3 \mathrm{~cm}$ in diameter) are likely pseudomorphs after andalusite. Rare pseudomorphs of sillimanite after kyanite wereal so found. 
This may indicate variability in pressure conditions in the Kangilinaaq belt or prograde Barrovian-style metamorphism. Q uartzo-feldspathic metasedimentary rocks in the central/northern part of the synform are coarse grained, heterogeneous, and rarely garnet-bearing.

The Q asigiannguit sequence comprises mafic and felsic metavolcanic rocks intercal ated with clastic sequences and isolated layers and lenses of strongly deformed, zebrastriped anorthosite. The sequenceis c. $700 \mathrm{~m}$ wide, trends $\mathrm{SW}-\mathrm{NE}$, and is well exposed on the islands south-west of $Q$ asigiannguit. The rocks are isoclinally folded with an intrafolially folded gneissic fabric. As mentioned above it is separated from the predominantly clastic sequence of Kangilinaaq by 200-500 m of high-strain Archaean orthogneiss (Fig. 2B; see also below). In contrast with the main supracrustal belt, the metamorphic grade is lower amphibolitefacies. T he fine to medium-grained, layered amphibolite contains hornblende and plagioclase, and minor clinopyroxene, epidote, biotite, quartz, and possibly also chlorite. $O$ nly along Laksebugt is the amphibolite locally garnet-bearing. Felsic layers can be up to several metres wide and contain predominantly plagioclase and quartz, with minor amphibole, white mica and titanite. Pelitic and semipelitic layers up to $50 \mathrm{~m}$ wide occur mainly on the islands south-west of $Q$ asigiannguit. These layers are generally schistose and contain predominantly quartz, plagioclase, biotite and minor garnet, whilesillimaniteand muscoviteare rare. In exposures $25 \mathrm{~km}$ north-east of Q asigiannguit, an outcrop of kyanite-bearing pelite shows no indications of replacement by sillimanite. Thisisthe only known occurrence in the north-eastern part of the $\mathrm{N}$ agssugtogidian orogen of stable kyanite, although this mineral has also been described from Archaean supracrustal rocks within the southern part of the Rinkian fold belt (Garde\& Steenfelt 1999). Fine-grained, dark grey biotiterich schist/gneiss forms layers $50-80 \mathrm{~m}$ wide that grade locally into layered amphibolites. H omogeneous, mediumgrained, greyish green, quartzo-feldspathic gneisses form layers up to $30 \mathrm{~m}$ wide that are generally platy and contain quartz, plagioclase, white mica, and amphibole. Their origin is uncertain. Their occurrence in a layered supracrustal sequence, without obvious intrusive contacts, could indicate that these rocks are also of supracrustal origin, but similar rocks in the main Kangilinaaq sequence grade into low-strain megacrystic granodiorite to quartz diorite. The contacts between the $\mathrm{Q}$ asigiannguit amphibolite and the regional Archaean orthogneiss are al ways tectonised, and their original contact relationships are uncertain. H owever, lenses of amphibolite, and locally also anorthosite, occur abundantly asinclusionsin theregional Archaean orthogneiss close to its contacts with the supra- crustal sequence. These lenses are unlikely to be tectonic because they occur in an irregular pattern, not along zones of high strain. It is more likely that they are xenoliths, suggesting that the orthogneiss precursors intruded into the supracrustal sequence.

\section{Aeromagnetic characteristics}

A eromagnetic data covering the I kamiut and Kangilinaaq regions (T horning 1993) allow us to image geological features in terms of magnetic responses, also in areas covered by lakes, sea and overburden. A spacing of flight lines of 1 $\mathrm{km}$ and a survey altitude of $500 \mathrm{~m}$ control the resolution of theaeromagnetic data. In order to en hancethe anomaly patterns from shallow-seated geological features, a separation filter has been applied (Jacobsen 1987). The filter enhances magnetic anomalies caused by geological features within a specific depth interval in the crust. The rationale of the filter is that the upward continuation of a potential field to a selected height represents the field from sources in the crust below half the selected height. The difference, or residual, between fields at two different heights can then be viewed as representing the field from sources within the corresponding depth interval in the crust. Thus, a total magnetic field that has been continued upward to a height of $2 \mathrm{~km}$ represents sources in the crust below $1 \mathrm{~km}$. Likewise, the field observed at $500 \mathrm{~m}$ represents sources below $250 \mathrm{~m}$. C onsequently, the residual obtained from these two fields by subtraction represents an enhanced image of the anomaly pattern of geological features in the depth interval $250 \mathrm{~m}-1 \mathrm{~km}$. The resulting 'subsurface' total magnetic field for thel kamiutKangilinaaq region is shown in Figs 3-5. In view of the fundamental ambiguity and complexity of the magnetic field separation, the filtering should only be used as a tool for detection of anomalies and discrimination of patterns, and qualitative interpretations should be supported by other types of geological data.

\section{Aeromagnetic patterns in the Ikamiut region}

The supracrustal rocks in the Ikamiut region appear as intermediate to low magnetic anomalies in the separationfiltered total magnetic field intensity map (-1 to - $30 \mathrm{nT}$, A's in Fig. 4). The orthogneisses are expressed as slightly higher magnetic anomalies (5-20 nT, B and C in Fig. 4), although these show considerable variability that may be a consequence of differing contributions from other subsurface lithologies. From the aeromagnetic anomalies it is 


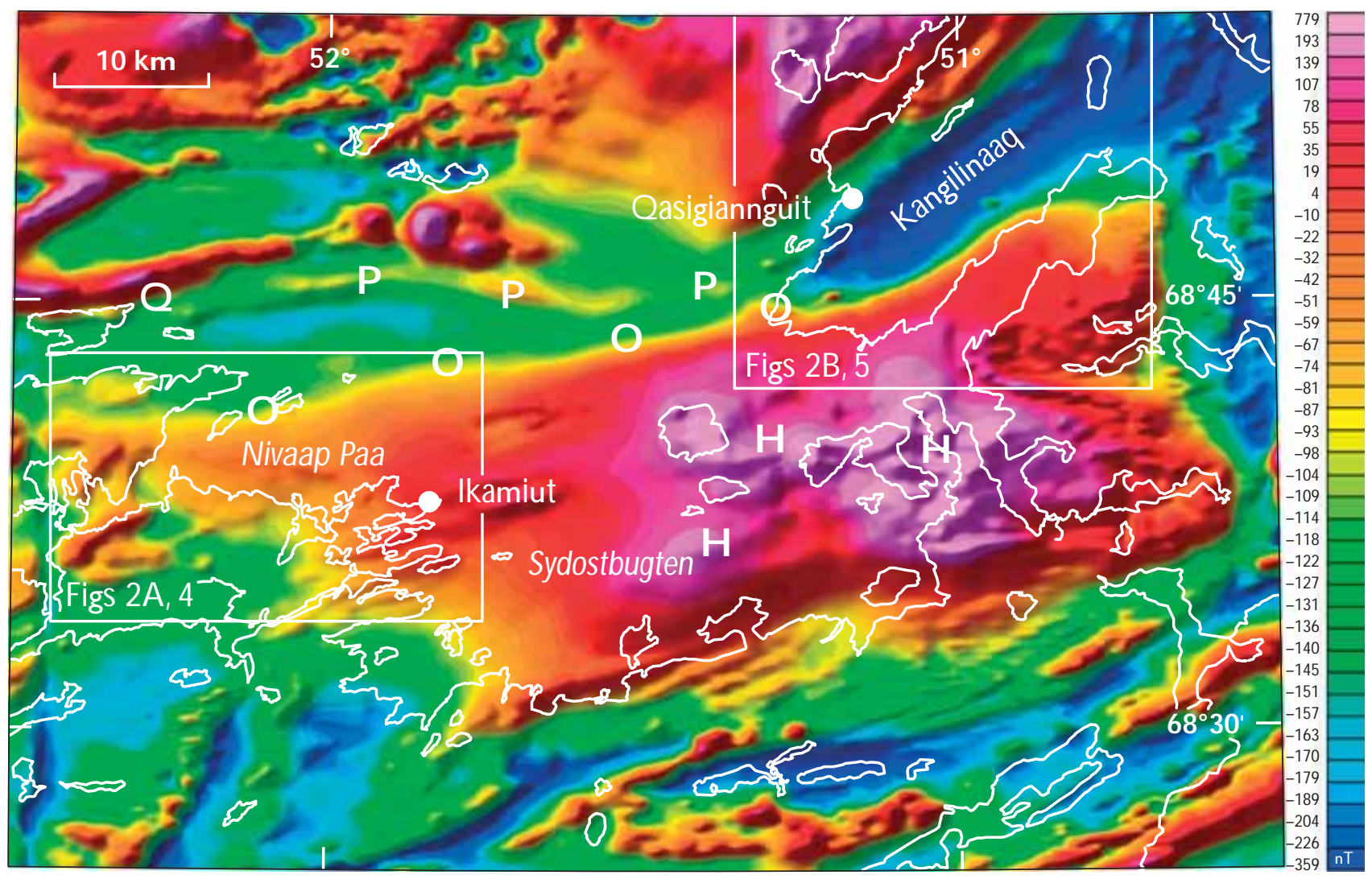

Fig. 3. Total magnetic field intensity for the I kamiut and Kangilinaaq regions. The labels $\mathbf{H}, \mathbf{O}, \mathbf{P}$ and $\mathbf{Q}$ are referred to in the main text. A shadowing effect from NW $\left(315^{\circ} \mathrm{N}\right)$ with an inclination of $45^{\circ}$ has been applied. The areas of Figs 4 and 5 are outlined by white frames.

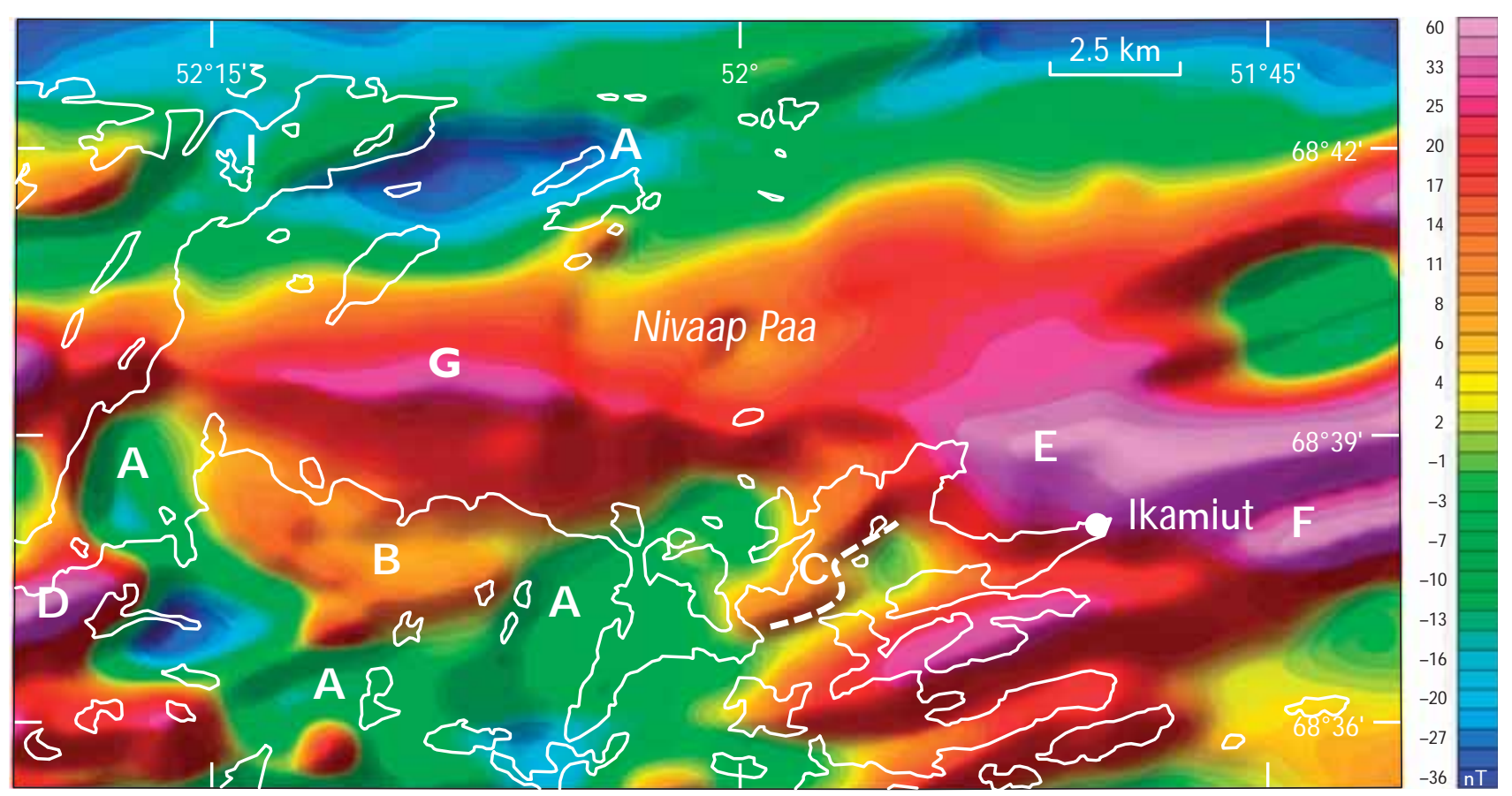

Fig. 4. The separation-filtered total magnetic field intensity in theinterval from $0.250 \mathrm{~m}-1 \mathrm{~km}$ for the l kamiut area. Shadowing effect as in Fig. 3. The labels A-I are referred to in the main text. 

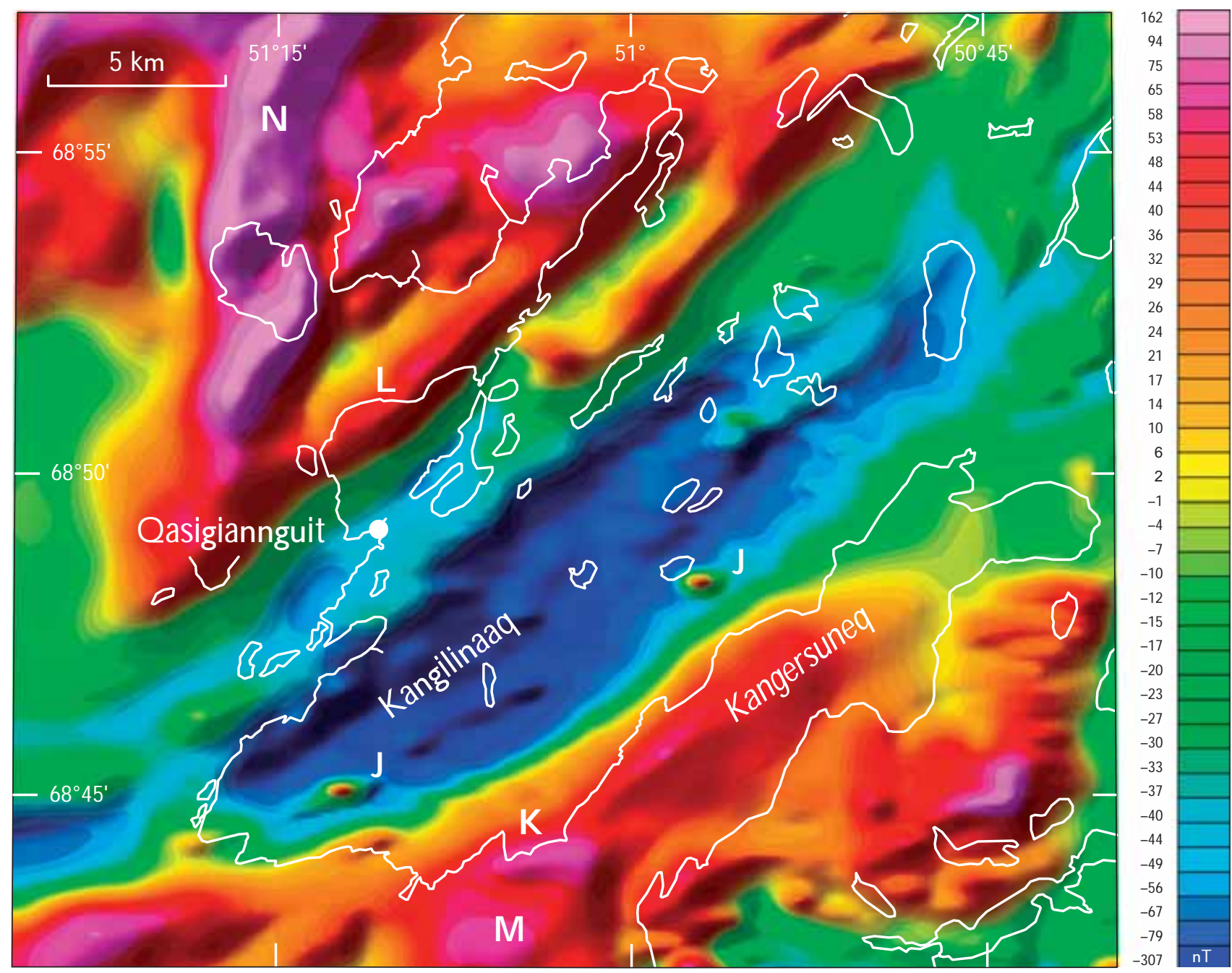

Fig. 5. The separation-filtered total magnetic field intensity in the interval from $0.250 \mathrm{~m}-1 \mathrm{~km}$ for the Kangilinaaq area. Shadowing effect as in Fig. 3. The labels $\mathbf{J}-\mathbf{N}$ are referred to in the main text.

possible to recognise folding of the orthogneiss (e.g. east of $C$, Fig. 4), which correlates closely with the geological mapping (Fig. 2A). Similarly, a strong magnetic low visiblebetween $B$ and $D$ (Fig. 4) defines a refolded fold structure in pelitic gneiss identified during mapping. Exposed granitic rocks are visible as high positive anomalies ( $D$, Fig. 4). Similar anomalies are visiblebeneath the sea north and east of I kamiut and beneath the bay of Nivaap Paa ( $E, F$ and $G$, Fig. 4). T he orthogneiss north of N ivaap Paa $(\mathrm{I}, \mathrm{Fig} .4)$ shows slightly lower magnetic anomalies than the orthogneisses to the south.

\section{Aeromagnetic patterns in the Kangilinaaq region}

The supracrustal belt on the Kangilinaaq peninsula appears as a distinct, rather homogeneous, low negative magnetic anomaly (-35 to - $300 \mathrm{nT}$, Fig. 5), possibly reflecting the dominance of quartzo-fel dspathic rocks with low magnetite contents. Small positive, short-wavelength, ovoid anomalies within the supracrustal rocks reflect small ultramafic bodies (J's, Fig. 5, too small to appear on the map of Fig. 2B). Thebiotite-bearing orthogneiss south of the supracrustal belt shows a positive magnetic anomaly (0-55 nT, K in Fig. 5). The change is rather abrupt and correlates with the ENE-trending mylonitic shear zone along the south-eastern margin of the supracrustal rocks close to the coast of the peninsula (see also Fig. 2B). The north-western boundary of the supracrustal belt on the opposite side of the peninsula, where supracrustal rocks and orthogneiss are interleaved, is less well defined. Farther north in the vicinity of Q asigiannguit, an abrupt change to a high positive magnetic anomaly field to the north-west corresponds with the northern contact of the amphibolite sequence against the orthogneiss ( $\mathrm{L}$ in Fig. 
5). The positivemagneticanomalies withintheorthogneiss domains immediately north and south of the Kangilinaaq peninsula ( $\mathrm{M}$ and $\mathrm{N}$ in Fig. 5) are much stronger than found within the orthogneiss in the north-eastern region of Fig. 5 (e.g. at $68^{\circ} 55^{\prime} \mathrm{N}, 50^{\circ} 45^{\prime} \mathrm{W}$ ). Based on similar strong positive anomalies associated with granitic rocks in the Ikamiut area (Fig. 4) and the porphyritic granite on the south-western tip of the Kangilinaaq peninsula (Fig. 5), the former anomalies may correspond to large deepseated granitic intrusives. Likewise, the large magnetic high at eastern Sydostbugten may represent granitic intrusive rocks hidden 1-2 km below the present surface (H 's, Fig. 3; Thorning 1993; N ielsen \& Rasmussen 2004).

\section{Geochronology}

Zircon separates from three samples from the I kamiut region were analysed to determine (1) theage of emplacement of the regional tonalitic to granodioritic orthogneiss, (2) the age distribution, provenance and minimum age of deposition of the sedimentary precursor to the Ikamiut metasedimentary rocks, and (3) the timing of metamorphism. Samples of two granodioritic orthogneisses and a quartzo-feldspathic metasedimentary rock were analysed, see below. Sample descriptions of these and other rocks are given in Table 1, and the age data are presented in Tables 2-3 and Figs 6-7. All age data in the text are quoted with $2 \sigma$ absolute uncertainty.

\section{Methodology}

Samples were crushed and sieved to $<400 \mu \mathrm{m}$. The fraction $<45 \mu \mathrm{m}$ was removed via washing and sieving and the remaining sample panned in water to concentrate the heavy fraction. T he heavy, nonmagnetic fraction was separated using heavy liquids $\left(3.30 \mathrm{gcm}^{-3}\right)$ and a Frantz magnetic separator. Zircons were hand-picked and mounted in epoxy resin. For secondary ion mass spectrometry (SIM S) analysis, grains were mounted together with 1065 M a zircons from reference sample 91500, O ntario, Canada (W iedenbeck et al. 1995). For laser inductively-coupled plasma mass spectrometry (LA-ICP-M S) analysis no zircon standard was used. The mounted samples were ground to expose the mid-sections of the zircons and polished. The polished samples were examined using backscattered el ectron (BSE) imaging on a Philips XL 40 scanning electron microscope at GEUS, operating at 20kV and a working distance of $10 \mathrm{~mm}$. Backscattered electron

Table 1. Sample descriptions

\begin{tabular}{|c|c|c|c|}
\hline Sample & Region & Rock type & Paragenesis \\
\hline $\begin{array}{l}467403 \\
467405 \\
467413 \\
467426 \\
467436 \\
467440 \\
467444 \\
467445 \\
467446\end{array}$ & $\begin{array}{l}\text { Kangilinaaq } \\
\text { Kangilinaaq } \\
\text { Kangilinaaq } \\
\text { Kangilinaaq } \\
\text { Kangilinaaq } \\
\text { Kangilinaaq } \\
\text { Kangilinaaq } \\
\text { Kangilinaaq } \\
\text { Kangilinaaq }\end{array}$ & $\left.\begin{array}{l}\text { Amphibolite } \\
\text { Fine-grained, layered amphibolite } \\
\text { Fine-grained, layered amphibolite } \\
\text { Fine-grained, layered amphibolite } \\
\text { Fine-grained, layered amphibolite } \\
\text { Fine-grained, layered amphibolite } \\
\text { Fine-grained, layered amphibolite } \\
\text { Fine-grained, layered amphibolite } \\
\text { Fine-grained, layered amphibolite } \\
\text { Fine-grained, layered amphibolite }\end{array}\right\}$ & hbl-pl \pm cpx \pm grt, accessory Fe-Ti oxides \\
\hline $\begin{array}{l}440938 \\
467526 \\
467401\end{array}$ & $\begin{array}{l}\text { Ikamiut } \\
\text { Ikamiut } \\
\text { Kangilinaaq }\end{array}$ & $\begin{array}{l}\text { Orthogneiss } \\
\text { Medium-grained granodioritic orthogneiss } \\
\text { Medium-grained granodioritic orthogneiss } \\
\text { Medium-grained tonalitic orthogneiss }\end{array}$ & $\begin{array}{l}\text { pl-qtz-ksp-bi } \\
\text { pl-qtz-ksp-bi } \\
\text { pl-qtz-bi }\end{array}$ \\
\hline $\begin{array}{l}440910 \\
440931 \\
467503 \\
467404 \\
467408 \\
467417 \\
467420 \\
467423 \\
467433\end{array}$ & $\begin{array}{l}\text { Ikamiut } \\
\text { Ikamiut } \\
\text { Ikamiut } \\
\text { Kangilinaaq } \\
\text { Kangilinaaq } \\
\text { Kangilinaaq } \\
\text { Kangilinaaq } \\
\text { Kangilinaaq } \\
\text { Kangilinaaq }\end{array}$ & $\begin{array}{l}\text { M etasedimentary rocks } \\
\text { Q uartzo-feldspathic gneiss } \\
\text { Q uartzo-feldspathic gneiss } \\
\text { Q uartzo-feldspathic gneiss } \\
\text { Garnet-bearing schist } \\
\text { C ummingtonite gneiss } \\
\text { Biotite-hornblende gneiss } \\
\text { Fine-grained schist } \\
\text { Hornblende gneiss } \\
\text { Hornblende gneiss }\end{array}$ & $\begin{array}{l}\text { pl-qtz-grt-bi, minor sill-ksp } \\
\text { pl-qtz-bi, minor ksp-mag. Bi partly replaced by chl } \\
\text { pl-qtz-bi, minor ksp-mag-mu } \\
\text { qtz-pl-bi-sill-grt. Bi partly replaced by sill } \\
\text { qtz-pl-bi-cu, minor hbl } \\
\text { qtz-pl-bi-hbl } \\
\text { qtz-pl-bi-ep, accessory al \& zn } \\
\text { hbl-pl, minor qtz, bi } \\
\text { hbl-pl, minor qtz, bi }\end{array}$ \\
\hline
\end{tabular}

Mineral abbreviations: al: allanite, bi: biotite, cpx: clinopyroxene, cu: Cummingtonite, ep: epidote, grt: garnet, hbl: hornblende, ksp: K-feldspar, mag: magnetite, mu: muscovite, pl: plagioclase, qtz: quartz, sill: sillimanite, ti: titanite, zn: zircon. 
Table 2. Zircon LA -IC P-MS ${ }^{207} \mathrm{~Pb}-{ }^{206} \mathrm{~Pb}$ data

\begin{tabular}{|c|c|c|c|c|c|c|c|c|c|c|c|c|c|c|}
\hline \multicolumn{5}{|c|}{ Spot ${ }^{206} \mathrm{~Pb}(\mathrm{cps}){ }^{207} \mathrm{~Pb} /{ }^{206} \mathrm{~Pb}$ Age (Ma) $2 \sigma \%$} & \multicolumn{5}{|c|}{ Spot ${ }^{206} \mathrm{~Pb}(\mathrm{cps}){ }^{207} \mathrm{~Pb} / 206 \mathrm{~Pb}$ Age (Ma) $2 \sigma \%$} & \multicolumn{5}{|c|}{ Spot ${ }^{206} \mathrm{~Pb}$ (cps) ${ }^{207} \mathrm{~Pb} / 206 \mathrm{~Pb}$ Age (Ma) $2 \sigma \%$} \\
\hline \multicolumn{5}{|c|}{440938 Granocioritic orthogneiss } & 91 & 54794 & 0.203058 & 2825 & 6.2 & 36 & 30037 & 0.201451 & 2808 & 6.6 \\
\hline 1 & 44913 & 0.207628 & 2847 & 4.8 & 92 & 86828 & 0.211233 & 2895 & 4.7 & 37 & 31254 & 0.193787 & 2730 & 7.6 \\
\hline 2 & 54464 & 0.206401 & 2843 & 6.1 & 93 & 86433 & 0.207258 & 2863 & 4.4 & 38 & 22041 & 0.205579 & 2827 & 10.1 \\
\hline 3 & 51744 & 0.211202 & 2865 & 10.9 & 94 & 41347 & 0.203007 & 2830 & 5.5 & 39 & 52491 & 0.162084 & 2504 & 10.1 \\
\hline 5 & 66847 & 0.205833 & 2818 & 12.1 & & & & & & 40 & 40780 & 0.194811 & 2741 & 5.7 \\
\hline 6 & 45663 & 0.239096 & 3072 & 7.3 & & & & & & 42 & 61409 & 0.195555 & 2747 & 4.9 \\
\hline 7 & 114515 & 0.203027 & 2811 & 4.9 & \multicolumn{5}{|c|}{ 467526 Granodioritic orthogneiss } & 43 & 103057 & 0.171459 & 2534 & 10.0 \\
\hline 10 & 29662 & 0.206933 & 2835 & 8.2 & 5 & 56698 & 0.200720 & 2804 & 5.3 & 44 & 40828 & 0.200096 & 2744 & 7.8 \\
\hline 12 & 81235 & 0.200267 & 2785 & 5.6 & 6 & 33787 & 0.193076 & 2748 & 6.6 & 45 & 58477 & 0.197715 & 2764 & 5.3 \\
\hline 15 & 63304 & 0.204663 & 2825 & 8.7 & 7 & 55326 & 0.195289 & 2762 & 4.8 & 46 & 20270 & 0.206049 & 2843 & 8.7 \\
\hline 16 & 58962 & 0.203500 & 2813 & 7.4 & 8 & 76699 & 0.182851 & 2652 & 4.9 & 47 & 33049 & 0.196133 & 2748 & 6.5 \\
\hline 17 & 32961 & 0.211432 & 2888 & 7.4 & 10 & 31196 & 0.183045 & 2654 & 6.6 & 48 & 28126 & 0.193760 & 2738 & 6.3 \\
\hline 20 & 86073 & 0.205326 & 2830 & 9.7 & 11 & 4904 & 0.204104 & 2807 & 12.9 & 50 & 19721 & 0.207732 & 2845 & 6.6 \\
\hline 21 & 125993 & 0.199600 & 2796 & 4.5 & 13 & 39648 & 0.191787 & 2718 & 5.5 & 51 & 86891 & 0.232092 & 2997 & 11.6 \\
\hline 25 & 60136 & 0.185466 & 2664 & 6.1 & 15 & 40707 & 0.202256 & 2816 & 5.0 & 52 & 58228 & 0.201806 & 2799 & 5.0 \\
\hline 26 & 48587 & 0.207014 & 2855 & 5.6 & 17 & 29635 & 0.217163 & 2844 & 19.1 & 53 & 50522 & 0.190800 & 2710 & 5.8 \\
\hline 27 & 98098 & 0.202412 & 2838 & 8.0 & 18 & 6853 & 0.206028 & 2827 & 14.9 & 54 & 60856 & 0.195334 & 2736 & 5.6 \\
\hline 28 & 46100 & 0.198084 & 2836 & 11.7 & 19 & 9339 & 0.206467 & 2995 & 5.7 & 55 & 35515 & 0.198275 & 2772 & 5.4 \\
\hline 29 & 44476 & 0.209520 & 2878 & 6.4 & & & & & & 56 & 51577 & 0.196653 & 2758 & 5.9 \\
\hline 30 & 55984 & 0.205825 & 2836 & 9.9 & & & & & & 58 & 27007 & 0.203361 & 2811 & 5.7 \\
\hline 31 & 52515 & 0.204633 & 2835 & 7.3 & \multicolumn{5}{|c|}{440910 Metasedimentary rock } & 59 & 49414 & 0.202192 & 2798 & 5.8 \\
\hline 33 & 60481 & 0.205708 & 2838 & 7.2 & 1 & 35535 & 0.200401 & 2828 & 6.5 & 62 & 10375 & 0.207836 & 2855 & 9.5 \\
\hline 34 & 41693 & 0.217275 & 2967 & 29.6 & 2 & 31197 & 0.211066 & 2824 & 10.1 & 63 & 120563 & 0.189864 & 2717 & 4.2 \\
\hline 40 & 16473 & 0.210866 & 2905 & 33.5 & 3 & 41461 & 0.193703 & 2741 & 6.1 & 64 & 23252 & 0.187771 & 2722 & 7.0 \\
\hline 41 & 63641 & 0.205836 & 2847 & 6.9 & 4 & 30241 & 0.204419 & 2821 & 6.0 & 65 & 26567 & 0.202492 & 2801 & 6.5 \\
\hline 42 & 26576 & 0.199429 & 2802 & 10.4 & 5 & 25534 & 0.191383 & 2718 & 5.6 & 69 & 89976 & 0.191213 & 2728 & 4.7 \\
\hline 43 & 34970 & 0.210589 & 2882 & 6.9 & 6 & 46366 & 0.198531 & 2774 & 6.1 & 70 & 25130 & 0.199809 & 2796 & 6.1 \\
\hline 44 & 66299 & 0.200725 & 2807 & 4.9 & 7 & 86549 & 0.207000 & 2846 & 5.7 & 71 & 68881 & 0.206577 & 2861 & 4.6 \\
\hline 47 & 76450 & 0.185001 & 2778 & 5.5 & 8 & 48635 & 0.201767 & 2807 & 5.3 & 72 & 53407 & 0.199076 & 2805 & 5.1 \\
\hline 48 & 344404 & 0.196981 & 2819 & 6.9 & 9 & 36751 & 0.209132 & 2858 & 7.0 & 73 & 51707 & 0.194570 & 2755 & 4.9 \\
\hline 50 & 94026 & 0.206532 & 2859 & 4.6 & 10 & 27744 & 0.183921 & 2654 & 9.9 & 74 & 67393 & 0.179579 & 2625 & 5.3 \\
\hline 54 & 32535 & 0.206805 & 2838 & 17.7 & 11 & 43029 & 0.194263 & 2742 & 6.7 & 75 & 30132 & 0.198104 & 2773 & 6.6 \\
\hline 55 & 18887 & 0.185070 & 2753 & 19.3 & 12 & 29314 & 0.172110 & 2520 & 8.6 & 76 & 36875 & 0.197163 & 2802 & 7.8 \\
\hline 57 & 45001 & 0.201119 & 2811 & 5.3 & 13 & 47160 & 0.206249 & 2841 & 5.9 & 77 & 28362 & 0.198893 & 2790 & 5.4 \\
\hline 59 & 63523 & 0.203583 & 2830 & 8.1 & 14 & 49306 & 0.201659 & 2804 & 7.0 & 78 & 27133 & 0.201214 & 2812 & 5.7 \\
\hline 60 & 35435 & 0.205041 & 2842 & 6.2 & 15 & 29978 & 0.198089 & 2779 & 6.0 & 79 & 133087 & 0.188329 & 2702 & 4.7 \\
\hline 61 & 23531 & 0.190093 & 2715 & 6.2 & 17 & 53134 & 0.194413 & 2748 & 5.4 & 80 & 45162 & 0.206677 & 2856 & 4.4 \\
\hline 63 & 112296 & 0.208790 & 2878 & 4.6 & 18 & 27856 & 0.201215 & 2810 & 6.9 & 81 & 51961 & 0.194173 & 2749 & 4.6 \\
\hline 64 & 39902 & 0.195071 & 2763 & 6.6 & 19 & 30082 & 0.205162 & 2842 & 5.9 & 83 & 27444 & 0.201457 & 2807 & 5.6 \\
\hline 74 & 19592 & 0.202403 & 2820 & 6.2 & 20 & 55684 & 0.198413 & 2780 & 5.1 & 84 & 26057 & 0.208900 & 2868 & 5.4 \\
\hline 75 & 30652 & 0.204612 & 2837 & 11.0 & 21 & 147594 & 0.191303 & 2722 & 5.3 & 85 & 31842 & 0.198490 & 2789 & 7.0 \\
\hline 77 & 41961 & 0.195999 & 2774 & 6.8 & 22 & 25436 & 0.210142 & 2870 & 7.0 & 86 & 114220 & 0.180764 & 2635 & 5.5 \\
\hline 78 & 64028 & 0.206406 & 2860 & 6.1 & 23 & 29257 & 0.196016 & 2766 & 7.0 & 87 & 62748 & 0.189371 & 2717 & 5.5 \\
\hline 80 & 30243 & 0.209704 & 2877 & 6.2 & 24 & 20655 & 0.203877 & 2826 & 6.4 & 88 & 42113 & 0.198204 & 2782 & 5.2 \\
\hline 81 & 106313 & 0.203552 & 2844 & 6.4 & 25 & 26159 & 0.201727 & 2796 & 6.6 & 89 & 24400 & 0.199600 & 2793 & 6.6 \\
\hline 82 & 47863 & 0.206121 & 2857 & 7.4 & 26 & 82319 & 0.215426 & 2917 & 4.5 & 90 & 29322 & 0.208314 & 2861 & 5.3 \\
\hline 83 & 58886 & 0.201354 & 2817 & 6.6 & 27 & 112103 & 0.194672 & 2751 & 5.1 & 91 & 75430 & 0.205029 & 2835 & 6.0 \\
\hline 84 & 119357 & 0.209519 & 2882 & 4.0 & 30 & 15491 & 0.200465 & 2794 & 7.1 & 93 & 24848 & 0.198066 & 2773 & 6.3 \\
\hline 86 & 93017 & 0.206130 & 2857 & 4.8 & 31 & 21709 & 0.204749 & 2831 & 8.0 & 95 & 60703 & 0.191617 & 2717 & 6.7 \\
\hline 87 & 59542 & 0.208843 & 2878 & 4.8 & 32 & 14364 & 0.206770 & 2843 & 11.0 & 96 & 40762 & 0.207364 & 2850 & 4.1 \\
\hline 88 & 80384 & 0.190889 & 2738 & 6.0 & 33 & 41967 & 0.201274 & 2800 & 6.8 & 97 & 131809 & 0.193200 & 2737 & 6.3 \\
\hline 89 & 56425 & 0.198658 & 2797 & 6.6 & 34 & 56320 & 0.189864 & 2710 & 5.6 & 98 & 43657 & 0.197222 & 2778 & 5.6 \\
\hline 90 & 52868 & 0.194667 & 2773 & 5.8 & 35 & 23757 & 0.202176 & 2801 & 9.1 & 99 & 17404 & 0.199360 & 2767 & 19.2 \\
\hline
\end{tabular}


Table 3.Zircon ion probe (SIMS) U-Th-Pb data

\begin{tabular}{|c|c|c|c|c|c|c|c|c|c|c|c|c|c|c|}
\hline \multirow[b]{2}{*}{ Spot } & \multirow[b]{2}{*}{$\begin{array}{c}U \\
\mathrm{ppm}\end{array}$} & \multirow[b]{2}{*}{$\begin{array}{l}\text { Th } \\
\mathrm{ppm}\end{array}$} & \multirow[b]{2}{*}{$\begin{array}{l}\mathrm{Pb} \\
\mathrm{ppm}\end{array}$} & \multirow[b]{2}{*}{$\begin{array}{c}\text { Th/U } \\
\text { measured }\end{array}$} & \multirow[b]{2}{*}{$f 206 \%$} & \multirow[b]{2}{*}{$\frac{207 \mathrm{~Pb}}{206 \mathrm{~Pb}}$} & \multirow[b]{2}{*}{$\sigma \%$} & \multirow[b]{2}{*}{$\frac{207 \mathrm{~Pb}}{235 \mathrm{U}}$} & \multirow[b]{2}{*}{$\sigma \%$} & \multirow[b]{2}{*}{$\frac{206 \mathrm{~Pb}}{238 \mathrm{U}}$} & \multirow[b]{2}{*}{$\sigma \%$} & \multirow[b]{2}{*}{$\begin{array}{l}\text { Discordance \% } \\
\text { (conventional) }\end{array}$} & \multicolumn{2}{|c|}{ Ages (Ma) } \\
\hline & & & & & & & & & & & & & $\frac{207 \mathrm{~Pb}}{206 \mathrm{~Pb}}$ & $\sigma$ \\
\hline \multicolumn{15}{|c|}{440938 Granodioritic orthogneiss } \\
\hline 3 & 155 & 94 & 113 & 0.607 & 0.04 & 0.19819 & 0.28 & 14.5789 & 1.06 & 0.53352 & 1.03 & -2.4 & 2811.3 & 4.6 \\
\hline 4 & 575 & 274 & 417 & 0.502 & 0.07 & 0.19781 & 0.18 & 14.8262 & 1.04 & 0.54361 & 1.03 & -0.4 & 2808.2 & 2.9 \\
\hline 8 & 192 & 24 & 127 & 0.117 & 0.05 & 0.19575 & 0.28 & 14.5329 & 1.07 & 0.53845 & 1.03 & -0.6 & 2791.1 & 4.6 \\
\hline 14 & 164 & 23 & 109 & 0.140 & 0.02 & 0.19767 & 0.38 & 14.7352 & 1.09 & 0.54065 & 1.03 & -0.9 & 2807.1 & 6.1 \\
\hline $20 a$ & 206 & 56 & 134 & 0.222 & 0.09 & 0.19216 & 0.30 & 13.6935 & 1.07 & 0.51684 & 1.03 & -3.3 & 2760.7 & 5.0 \\
\hline 24 & 175 & 37 & 117 & 0.170 & 0.05 & 0.19891 & 0.31 & 14.7222 & 1.07 & 0.53682 & 1.03 & -2.1 & 2817.2 & 5.0 \\
\hline 29 & 578 & 153 & 384 & 0.217 & 0.23 & 0.19498 & 0.17 & 14.2171 & 1.04 & 0.52885 & 1.03 & -2.1 & 2784.6 & 2.8 \\
\hline 41 & 632 & 35 & 391 & 0.054 & 0.01 & 0.19138 & 0.14 & 13.5355 & 1.04 & 0.51295 & 1.03 & -3.8 & 2754.1 & 2.4 \\
\hline 54 & 273 & 155 & 199 & 0.555 & 0.09 & 0.19767 & 0.29 & 14.6540 & 1.07 & 0.53768 & 1.03 & -1.5 & 2807.0 & 4.8 \\
\hline 66 & 251 & 227 & 191 & 0.878 & 0.07 & 0.19836 & 0.23 & 14.3381 & 1.05 & 0.52425 & 1.03 & -4.2 & 2812.7 & 3.7 \\
\hline 72 & 203 & 158 & 150 & 0.762 & 0.09 & 0.19789 & 0.29 & 14.2560 & 1.07 & 0.52248 & 1.03 & -4.3 & 2808.9 & 4.7 \\
\hline 76 & 157 & 49 & 107 & 0.307 & 0.02 & 0.20014 & 0.33 & 14.6609 & 1.09 & 0.53127 & 1.04 & -3.5 & 2827.4 & 5.4 \\
\hline \multicolumn{15}{|c|}{440910 Metasedimentary rock } \\
\hline 22 & 850 & 51 & 526 & 0.057 & 0.01 & 0.18523 & 0.20 & 13.1609 & 1.78 & 0.51532 & 1.77 & -0.9 & 2700.3 & 3.4 \\
\hline 29 & 480 & 2 & 308 & 0.002 & 0.03 & 0.18986 & 0.27 & 14.0987 & 1.79 & 0.53857 & 1.77 & 1.6 & 2740.9 & 4.4 \\
\hline 42 & 609 & 3 & 390 & 0.003 & 0.05 & 0.18800 & 0.22 & 13.9521 & 1.78 & 0.53823 & 1.77 & 2.3 & 2724.8 & 3.6 \\
\hline 54 & 554 & 2 & 344 & 0.004 & 0.01 & 0.18507 & 0.22 & 13.3561 & 1.78 & 0.52342 & 1.77 & 0.7 & 2698.8 & 3.6 \\
\hline $58 c$ & 106 & 32 & 71 & 0.275 & 0.23 & 0.19043 & 0.43 & 14.0439 & 1.82 & 0.53488 & 1.77 & 0.7 & 2745.9 & 7.1 \\
\hline $58 r$ & 610 & 2 & 378 & 0.003 & 0.04 & 0.18916 & 0.21 & 13.6001 & 1.79 & 0.52146 & 1.77 & -1.3 & 2734.8 & 3.5 \\
\hline 82 & 1178 & 7 & 730 & 0.004 & 0.07 & 0.18473 & 0.17 & 13.3129 & 1.78 & 0.52267 & 1.77 & 0.7 & 2695.8 & 2.9 \\
\hline
\end{tabular}

Errors on ratios and ages are quoted at the $1 \sigma$ level.

c: core; $r$ : rim; f $206 \%$ :The fraction of common ${ }^{206} \mathrm{~Pb}$, estimated from the measured $204 \mathrm{~Pb}$.

$\mathrm{D}$ iscordance \%: D egree of discordance of the zircon analysis (at the centre of the error ellipse).

(BSE) images of some of the analysed grains showing sites of analysis and ages obtained are presented in Fig. 6.

All three samples were analysed at GEUS using a PerkinElmer 6100 DRC quadrupole inductively-coupled plasma mass spectrometer combined with a Cetac LSX 200 laser ablation unit based on a solid-state $\mathrm{N} \mathrm{d-YAG}$ laser, emitting at a wavelength of $266 \mathrm{~nm}$. The laser was operated at $20 \mathrm{~Hz}$ with a spot size of $30 \mu \mathrm{m}$, producing pits of c. $50 \mu \mathrm{m}$ depth. The masses ${ }^{208} \mathrm{~Pb},{ }^{207} \mathrm{~Pb},{ }^{206} \mathrm{~Pb}$, and ${ }^{204} \mathrm{~Pb}$ were analysed in line scans run at $1 \mu \mathrm{m}$ per second. Each analysis comprised 150 time-resolved replicates (duration of total analysis $150 \mathrm{~s}$ ). In the case of small grains with diameters $<100 \mu \mathrm{m}$, only 100 replicates over $100 \mathrm{~s}$ were collected. I inconsistenciesin themeasured ratioswere identified within the time span of each analysis, such as spikes relating to inclusions, or significant changesin $\mathrm{Pb}$ $\mathrm{Pb}$ ratios indicative of sampling of different age zones, then the whole analysis was discarded. The analyses were standardised against N IST 610 glass (Pearce et al. 1997) to account for instrument drift. The influence of common $\mathrm{Pb}$ cannot be assessed using this method, since ${ }^{204} \mathrm{~Pb}$ was generally below the detection limit. Also, because $U$ isotopes could not be measured, the significance of $\mathrm{Pb}$ loss cannot beassessed, and therefore the ages determined should be regarded as minimum ages. In addition, the age resolution on any individual analysis was restricted owing to relatively low count rates obtained. However, it is a great advantage of the LA-ICP-M S method that a large number of analyses can be made within a short time period, allowing analysis of large numbers of grains in samples with isotopically simplezircon. T he LA-ICP-M S age data are presented in Table 2 and as histograms coupled with relative probability curves (Fig. 7).

SIM S analysis of zircon from two samples (440938, 440910) was carried out using a CAM ECA IM S 1270 secondary ion mass spectrometer at the N O RD SIM laboratory, Swedish M useum of N atural H istory, Stockholm. The polished zircon mounts were coated with a c. $30 \mathrm{~nm}$ layer of gold. Analytical procedures and common lead corrections are similar to those described by Whitehouse et al. (1997). A primary $0^{2-}$ ion beam is focussed into a spot with a diameter of $20 \mu \mathrm{m}$ that sputters material from the sample to leave a flat-bottomed crater. Positive ions sputtered from the crater are extracted and mass-separated into the peaks of interest: ${ }^{90} \mathrm{Zr}_{2}{ }^{16} \mathrm{O},{ }^{204} \mathrm{~Pb},{ }^{206} \mathrm{~Pb},{ }^{207} \mathrm{~Pb}$, ${ }^{208} \mathrm{~Pb},{ }^{238} \mathrm{U},{ }^{232} \mathrm{~T} \mathrm{~h}{ }^{16} \mathrm{O}$, and ${ }^{238} \mathrm{U}{ }^{16} \mathrm{O}$. Calibrations of $\mathrm{Pb} / \mathrm{U}$ ratiosarebased on theobserved relationship between $\mathrm{Pb} / \mathrm{U}$ and $\mathrm{UO}_{2} / \mathrm{U}$. Weighted average ${ }^{207} \mathrm{~Pb} /{ }^{206} \mathrm{~Pb}$ ages were calculated using ISO PLOT (Ludwig 2000). SI M S age data are presented in Table 3 and on Tera-Wasserburg diagrams in Fig. 7. 


\section{Orthogneiss}

The two samples of granodioritic orthogneiss sel ected for geochronology (440938 and 467526) were collected at the south coast of Langesund (Fig. 2A). Sample descriptions and chemical composition are presented in Tables 1 and 4. Sample 440938 yielded abundant zircon and contains common thin, transposed granitic layers, whereas sample 467526 does not contain such granitic leucosome. The zircons from both samples are 100-600 $\mu \mathrm{m}$ (mostly c. 200-300 $\mu \mathrm{m}$ ) in length and translucent with a heterogeneous orange colour. The crystals are euhedral with slightly rounded terminations and aspect ratios from 1:2.5-1:4, typically c. 1:3. Broad oscillatory zonesc. 10$30 \mu \mathrm{m}$ wide are very common, with rare development of bright, presumably metamorphic rims (see below). The zircons are commonly weakly to moderately fractured, both concentrically and radially, and often show partial fracture healing within bright oscillatory zones (Fig. 6).

LA-ICP-M S analyses of 57 oscillatory zoned grainsfrom sample 440938 give a weighted mean age of $2831 \pm 23$ M a $(2 \sigma$, M SW D = 0.36; Table 2; Fig. 7A). Ten SIM S analyses of cores of oscillatory zoned grains and two of bright rims reveal more age complexity, with seven of the cores yielding an important 2820-2810 M a age component (Table 3; Fig. 7B, black data ellipses). Four of these seven analyses lie slightly off concordia. Another, slightly older and likewise discordant grain (2827 M a, blue in Fig. 7B) belongs to the $2831 \pm 23 \mathrm{M}$ a LA-IC P-M S age group. $M$ any of the analysed grains show slight discordance indicating partial $\mathrm{Pb}$ loss, the timing of which is unclear from the data available. Two bright rims with significantly younger ages of $2761 \pm 10 \mathrm{M}$ a and $2754 \pm 5 \mathrm{M}$ a are interpreted as metamorphic. This is supported by the very low $\mathrm{Th} / \mathrm{U}$ of thelatter (0.054), though the former is not anomalous in this respect ( $\mathrm{Th} / \mathrm{U}=0.22$ ). $\mathrm{T}$ he SIM S data are slightly but significantly younger than the LA-ICP-M S data for the same sample (but from different analysed grains), although the $2 \sigma$ error on the LA-ICP-M S age spectrum encompasses most of the SIM $S$ data. It is difficult to establish the reason for this, particularly given the apparent complexity of thezircons (Fig. 7B). It is possible that a larger proportion of older material has been sampled in the LA-ICP-M S work. It may al so be that matrix effects had some influence in standardising zircon data against N IST 610 glass, though such effects are not generally regarded as significant.

The few zircons separated from sample 467526 were analysed via LA-ICP-M S. Eleven analyses of cores displaying oscillatory zonation yield a poorly constrained weighted mean age of $2741 \pm 53 \mathrm{M} \mathrm{a}(2 \sigma, \mathrm{M}$ SWD $=0.55$; Fig. $7 \mathrm{C})$.
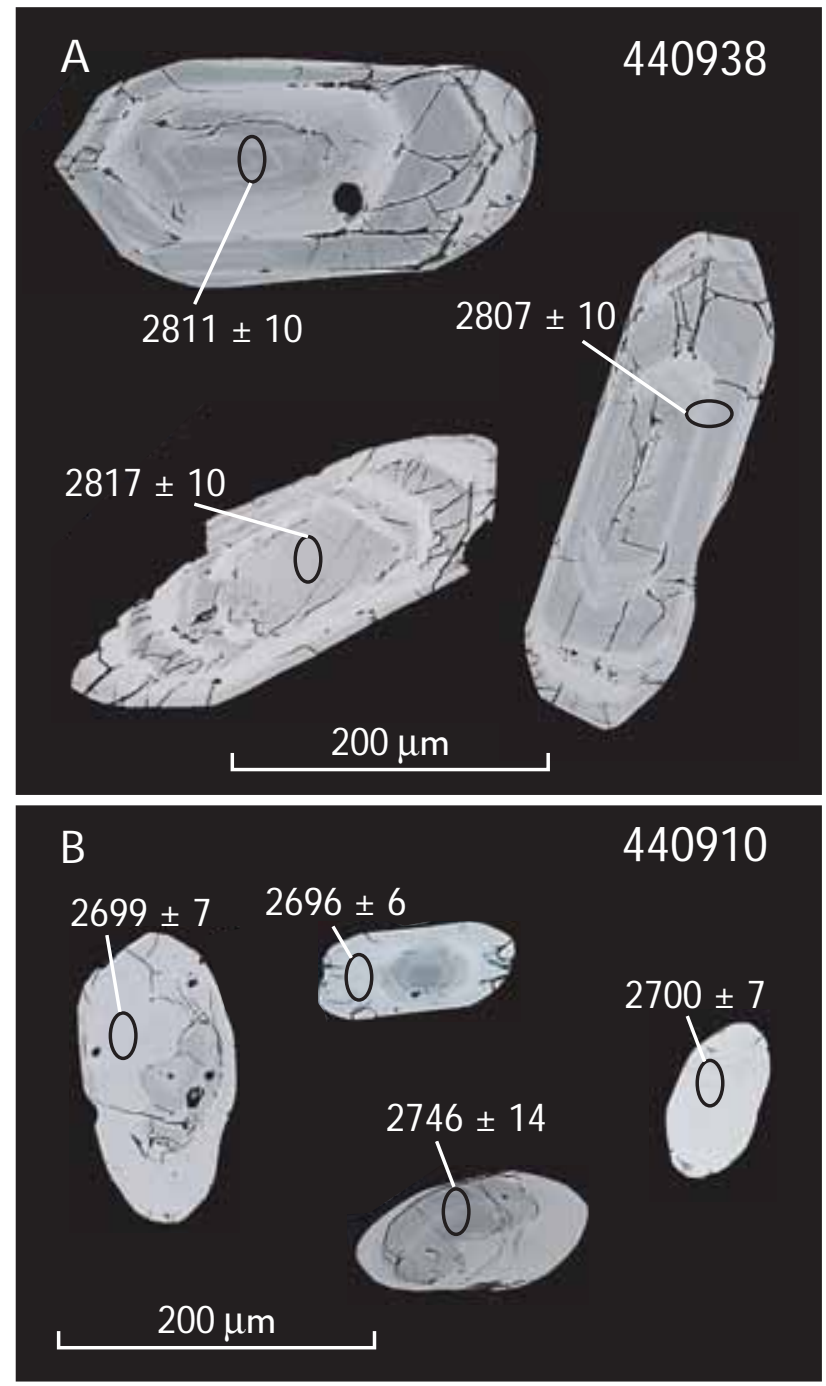

Fig. 6. Backscattered electron images of zircons in samples 440938 (orthogneiss) and 440910 (metasediment) analysed via SIM S, showing analysed areas and ages obtained.

It might be considered that the large analytical error for this sample leaves room for age complexity, possibly involving analysis of both inherited grains and $\mathrm{Pb}$ loss (similar to sample 440938). H owever, all analyses statistically belong to the same population, and there are no significant differences in internal zircon morphology that might account for different age groups.

\section{Metasedimentary rocks}

Sample 440910 from the Ikamiut belt (Fig. 2A) is a medium-grained, garnet-bearing quartzo-feldspathic, gneissic rock. Colourless, paleyellow and pale pink zircon grains are abundant. They are elongate and generally 100-200 

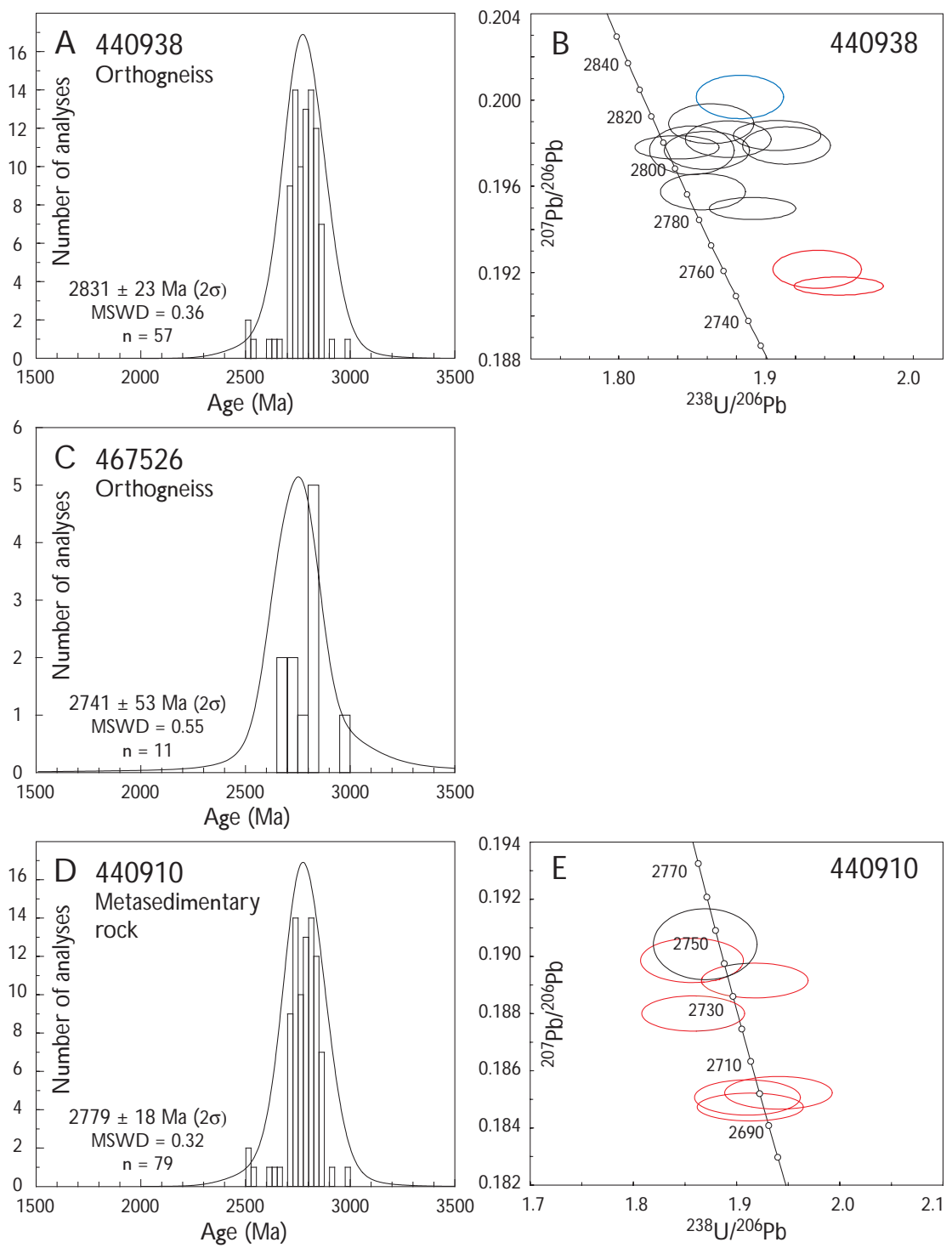

Fig. 7. LA-ICP-MS S ${ }^{207} \mathrm{~Pb} /{ }^{206} \mathrm{~Pb}$ histograms and SIM S U-Pb Tera-Wasserburg concordia plots of zircon age data from the l kamiut region. A: H istogram of ${ }^{207} \mathrm{~Pb} / 206 \mathrm{~Pb}$ ages from orthogneiss sample 440938. B: TeraWasserburg plot for orthogneiss sample 440938 showing nine cores of oscillatoryzoned grains (black), an older core (blue), and two bright rims (red). C, D : H istograms of ${ }^{207} \mathrm{~Pb} / 206 \mathrm{~Pb}$ ages from orthogneiss 467526 and metasedimentary sample 440910. E: Tera-Wasserburg plot for metasedimentary sample 440910 showing one core (black) and six metamorphic rims (red). The histogram bin size is $25 \mathrm{Ma}(\mathrm{A}$, D) or $50 \mathrm{Ma}$ (C). Error ellipses on concordia diagrams are drawn at $68.3 \%$ confidence $(1 \sigma)$. $\mu \mathrm{m}$ in length, with rounded terminations and aspect ratios of 1:1-1:3, typically c. 1:2. BSE imaging reveals relatively wide (c. 10-30 $\mu \mathrm{m}$ ) oscillatory zoned cores with moderateto well-developed bright rimsc. 10-60 $\mu$ m wide, which in many cases have anneal ed former fractures (Fig. 6).

${ }^{207} \mathrm{~Pb}-{ }^{206} \mathrm{~Pb}$ ages from $87 \mathrm{LA}-\mathrm{ICP}-\mathrm{M} S$ analyses of oscillatory zoned zircon cores are shown in Fig. 7D. The vast majority (79) define a tightly clustered peak at c. 2800 $\mathrm{M} \mathrm{a}$. The complete age range spans 2997-2520 $\mathrm{M}$ a. The youngest ages $(<2700 \mathrm{M}$ a) may reflect mixed core-rim data, although most of them are statistically within the main age population. If a few anomalous old and young ages are disregarded, a weighted mean age of $2779 \pm 18$ $M$ a is obtained $(2 \sigma, M S W D=0.32, n=79)$. T his group is interpreted as comprising a homogeneous population of detrital zircons, consistent with local derivation from orthogneiss of this age (see above). Seven SI M S analyses, of one core with oscillatory zonation and six bright rims, all fall on concordia (Fig. 7E). The core gives the oldest age of $2746 \pm 14 \mathrm{M} \mathrm{a}(\mathrm{Th} / \mathrm{U}=0.275)$. The six analyses of bright rims give ages between $2741 \pm 9$ and $2696 \pm 6 \mathrm{M} \mathrm{a}$. All have very low $\mathrm{T} h / \mathrm{U}(0.004-0.06)$, consistent with a metamorphic origin. These metamorphic ages are comparable to the few young ages also identified in the LAICP-M S analyses, and suggest that this sample underwent metamorphism at c. 2740-2700 M a, shortly after its deposition. An alternative, and in our view less likely interpre tation is that the metamorphic rims were developed during metamorphism of the source rock prior to erosion and deposition of the sediment. 


\section{Geochemistry}

Whole-rock geochemical analysis of amphibolites, felsic orthogneiss and metasedimentary rocks from the lkamiut and $K$ angilinaaq regions was undertaken to (a) geochemically characterise these rock types, (b) investigate the likely tectonic environment of formation and provenance of the amphibolites and metasedimentary rocks, and (c) investigatelikely regional correlations. Sample descriptionsare presented in Table 1, and major and trace element compositions in Table 4.

\section{A nalytical procedure}

$M$ ajor and trace element analyses (Table4) were performed by GEUS. The samples were ground in tungsten (I kamiut samples) or agate (Kangilinaaq samples) mills, and dried. For major elements the rock powders were fluxed with sodium tetraborate and fused to glass discs and analysed with a Philips PW 1606 X-ray fluorescence (XRF) mass spectrometer. $\mathrm{N}$ a and $\mathrm{C} u$ were determined by atomic absorption spectrometry, and volatiles were analysed by gravimetry. Refer to K ystol \& Larsen (1999) for the complete analytical procedure. For trace element analyses, powdered samples were brought into solution and analysed using a PerkinEImer 6100 D RC Q uadrupole ICPM S instrument. For the Ikamiut samples $\mathrm{Zr}, \mathrm{Cr}$, REEs and $\mathrm{H} f$ were determined by dissolving a piece of the borate glass used in the major element XRF analyses, in order to obtain completecontributionsof theseelementsfrom chromite and zircon. The ICP-M S results were corrected for the relevant oxide interferences using BH VO -1 and $\mathrm{GH}$ as standards.

For the Kangilinaaq samples some trace el ements were also analysed by XRF performed directly on pressed powder tablets at the Geological Institute, University of C Openhagen, using a Phillips PW 1400 XRF spectrometer. The data were corrected for matrix variations using the major element compositions, and AG V-1 was run as standard.

\section{Orthogneisses}

Two orthogneiss samples from the Ikamiut region were analysed (440938 and 467526), and one from Kangilinaaq (467401; Table 4a; Fig. 2). The two I kamiut samples show very similar granodioritic major element chemistry, while the K angilinaaq sample is more tonalitic. The Kangilinaaq sample has low REE concentrations and a fairly steep REE curve with $L a_{N} / L u_{N} \sim 16$ (Fig. 8B). In contrast, the two Ikamiut samples have higher REE concentrations and significant negative Eu anomalies, consistent with the more evolved composition of these rocks.

\section{A mphibolites from the Kangilinaaq belt}

$\mathrm{N}$ ine amphibolites S.S. from the Kangilinaaq belt were analysed for major and trace elements (Table 4a); no amphibolite samples have been analysed from the I kamiut region, where amphibolites only constitute a minor component of the supracrustal rocks. The nine samples from Kangilinaaq show only a small range in chemical composition. They have relatively primitive signatures with low $\mathrm{SiO}_{2}(46-49 \mathrm{wt} \%)$ and high $\mathrm{M} \mathrm{gO}(7-11 \mathrm{wt} \%)$, and flat REE patterns that group tightly around ten times chondrite values (Fig. 8A). Their Ti/V ratios display a narrow range of 16-19, and in a Ti-V diagram (Shervais 1982) they plot just within theisland arc field (Fig. 9). The positive correlation between $\mathrm{T} i$ and $\mathrm{V}$ could reflect fractionation of olivine and plagioclase. The geochemical resemblance between all nine samples and their well-defined $\mathrm{Ti} / \mathrm{V}$ trend are consistent with formation within a single volcanic suite.

Metasedimentary rocks and hornblendebearing gneisses from the Kangilinaaq belt

M etasedimentary sample 467404 is characterised by high alumina (19 wt\%) coupled to low CaO (0.7 wt\%) and high concentrationsof REE and $\mathrm{Ba}(605 \mathrm{ppm})$, consistent with a clay-rich precursor. T heREE curveissteep $\left(\mathrm{La}_{\mathrm{N}} / \mathrm{Lu}_{\mathrm{N}}\right.$ $=30, \mathrm{La}=140$ times chondrite), and has a significantly negative Eu anomaly. Sample 467420 is siliceous (75 wt\% $\mathrm{SiO}_{2}$ ), consistent with a relatively mature sedimentary precursor. Its REE concentrations lie just bel ow those of sample 467404, with a similar steep REE pattern. For sample 467417, both major and trace elements agree well with the average composition of Archaean mudstone from Taylor \& M CLennan (1985, table 7.8). The REE curve resembles that of sample 467408 (see below), although it has slightly lower concentrations of the H REE.

The hornblende-bearing gneisses 467423 and 467433 were collected from thin $(<1 \mathrm{~m})$ amphibolite units within metasedimentary sequences. The geochemical compositions of these two samples are close to those of the nine amphibolite samples described above, and they can only be distinguished from the latter by their higher concentrations of $\mathrm{LREE}, \mathrm{Ba}$, and $\mathrm{Sr}$, and higher $\mathrm{K}_{2} \mathrm{O}$ and $\mathrm{Rb}$ in 
Table 4a. Chemical analyses of amphibolite and orthogneiss

\begin{tabular}{|c|c|c|c|c|c|c|c|c|c|c|c|c|}
\hline & \multicolumn{9}{|c|}{ Amphibolite, Kangilinaaq belt } & \multicolumn{3}{|c|}{ O rtho gneiss } \\
\hline & 467403 & 467405 & 467413 & 467426 & 467436 & 467440 & 467444 & 467445 & 467446 & 440938 & 467526 & 467401 \\
\hline $\mathrm{SiO}_{2}$ & 48.73 & 48.72 & 49.3 & 46.86 & 48.39 & 47.37 & 48.01 & 48.25 & 46.00 & 71.93 & 71.70 & 68.86 \\
\hline $\mathrm{TiO}_{2}$ & 1.03 & 0.87 & 0.83 & 0.60 & 0.64 & 0.66 & 0.90 & 0.88 & 0.75 & 0.24 & 0.39 & 0.22 \\
\hline $\mathrm{Al}_{2} \mathrm{O}_{3}$ & 13.16 & 15.81 & 14.61 & 16.21 & 15.68 & 16.36 & 13.29 & 12.18 & 16.25 & 14.58 & 14.64 & 16.93 \\
\hline $\mathrm{Fe}_{2} \mathrm{O}_{3}$ & 1.67 & 2.54 & 2.7 & 1.88 & 2.13 & 2.79 & 1.90 & 1.88 & 2.83 & 1.99 & 2.09 & 0.09 \\
\hline $\mathrm{FeO}$ & 10.64 & 8.89 & 9.11 & 7.48 & 7.85 & 8.14 & 8.04 & 8.82 & 7.94 & 0.00 & 0.00 & 1.68 \\
\hline $\mathrm{FeO} *$ & 12.14 & 11.17 & 11.53 & 9.17 & 9.77 & 10.65 & 9.75 & 10.51 & 10.49 & 1.79 & 1.88 & 1.76 \\
\hline $\mathrm{MnO}$ & 0.22 & 0.21 & 0.20 & 0.18 & 0.17 & 0.16 & 0.13 & 0.19 & 0.17 & 0.01 & 0.02 & 0.02 \\
\hline $\mathrm{MgO}$ & 8.82 & 6.90 & 7.73 & 8.30 & 8.34 & 9.37 & 10.74 & 11.15 & 10.04 & 0.57 & 0.57 & 0.98 \\
\hline $\mathrm{CaO}$ & 11.46 & 12.72 & 11.51 & 14.17 & 12.78 & 10.91 & 12.31 & 12.43 & 10.42 & 2.02 & 2.12 & 4.02 \\
\hline $\mathrm{Na}_{2} \mathrm{O}$ & 2.25 & 1.28 & 1.58 & 1.60 & 1.36 & 2.00 & 1.97 & 1.56 & 2.38 & 4.47 & 4.70 & 5.17 \\
\hline $\mathrm{K}_{2} \mathrm{O}$ & 0.11 & 0.23 & 0.25 & 0.31 & 0.25 & 0.08 & 0.52 & 0.10 & 0.48 & 3.08 & 2.31 & 1.05 \\
\hline $\mathrm{P}_{2} \mathrm{O}_{5}$ & 0.06 & 0.06 & 0.05 & 0.04 & 0.04 & 0.04 & 0.06 & 0.06 & 0.05 & 0.07 & 0.08 & 0.07 \\
\hline Volatiles & 1.58 & 1.5 & 1.57 & 1.48 & 1.57 & 1.6 & 1.43 & 1.53 & 2.06 & 0.27 & 0.10 & 0.53 \\
\hline Sum & 99.74 & 99.72 & 99.43 & 99.11 & 99.21 & 99.47 & 99.29 & 99.02 & 99.36 & 99.23 & 98.71 & 99.62 \\
\hline Sc & 53.6 & 49.0 & 54.8 & 44.1 & 44.2 & 38.7 & 49.6 & 52.3 & 49.7 & 5.5 & 8.1 & 4.6 \\
\hline V & 347 & 283 & 308 & 214 & 237 & 220 & 301 & 297 & 256 & 16 & 13.8 & 24.1 \\
\hline $\mathrm{Cr}$ & 106 & 301 & 380 & 444 & 450 & 207 & 521 & 485 & 411 & 5.0 & 2.6 & 35.9 \\
\hline $\mathrm{Co}$ & 53.5 & 55.1 & 51.6 & 51.2 & 56.1 & 58.0 & 70.3 & 56.6 & 54.0 & 17.2 & 14.7 & 6.0 \\
\hline $\mathrm{Ni}$ & 117 & 150 & 160 & 221 & 222 & 254 & 214 & 221 & 159 & 3.6 & 3.4 & 12.9 \\
\hline $\mathrm{Cu}$ & 64.2 & 89.0 & 82.7 & 39.1 & 90.3 & 89.5 & 4.8 & 82.8 & 80.8 & 2.4 & 8.1 & 7.3 \\
\hline $\mathrm{Zn}$ & 91.9 & 86.0 & 92.2 & 74.3 & 74.8 & 80.1 & 40.0 & 77.3 & 74.6 & 40.9 & 39.8 & 45.2 \\
\hline $\mathrm{Ga}$ & 15.7 & 16.3 & 15.7 & 14.2 & 14.2 & 14.8 & 14.8 & 14.1 & 15.4 & 18.2 & 20.8 & 23.2 \\
\hline $\mathrm{Rb}$ & 1.1 & 7.6 & 9.1 & 12.4 & 10.9 & 1.2 & 9.5 & 2 & 10.6 & 82.1 & 91.4 & 92.9 \\
\hline $\mathrm{Sr}$ & 124 & 111 & 91 & 118 & 150 & 100 & 94 & 109 & 155 & 385 & 303 & 375 \\
\hline$Y$ & 19.6 & 19.5 & 19.6 & 13.6 & 14.3 & 14.2 & 18.1 & 17.4 & 17 & 3 & 7.8 & 2.8 \\
\hline $\mathrm{Zr}$ & 29.7 & 11.8 & 12.5 & 9.4 & 9.4 & 15.8 & 18.4 & 11.6 & 16.2 & 143 & 117 & 57.9 \\
\hline $\mathrm{Nb}$ & 3.1 & 2 & 1.9 & 1.5 & 1.4 & 1.1 & 2.4 & 2.2 & 1.7 & 2.5 & 4.9 & 15.4 \\
\hline $\mathrm{Cs}$ & 0.0 & 0.3 & 0.2 & 0.7 & 0.8 & 0.0 & 0.1 & 0.0 & 0.2 & 1.2 & 2.6 & 5.6 \\
\hline $\mathrm{Ba}$ & 18 & 56 & 43 & 47 & 25 & 6 & 31 & 20 & 60 & 748 & 446 & 210 \\
\hline La & 3.2 & 2.2 & 2.4 & 1.7 & 1.6 & 1.6 & 3.5 & 2.5 & 2.2 & 34.1 & 18.9 & 4.0 \\
\hline $\mathrm{Ce}$ & 8.4 & 6.0 & 6.3 & 4.5 & 4.3 & 4.3 & 8.0 & 6.5 & 6.0 & 65.0 & 37.8 & 8.3 \\
\hline $\mathrm{Pr}$ & 1.3 & 1.0 & 1.0 & 0.7 & 0.7 & 0.7 & 1.2 & 1.0 & 0.9 & 7.2 & 4.2 & 1.0 \\
\hline $\mathrm{Nd}$ & 6.7 & 5.3 & 5.3 & 3.7 & 3.7 & 3.7 & 6.0 & 5.6 & 5.1 & 24.2 & 14.9 & 3.7 \\
\hline $\mathrm{Sm}$ & 2.2 & 1.8 & 1.8 & 1.4 & 1.4 & 1.3 & 1.9 & 1.9 & 1.7 & 3.3 & 2.5 & 0.8 \\
\hline Eu & 0.7 & 0.7 & 0.7 & 0.5 & 0.5 & 0.6 & 0.7 & 0.7 & 0.6 & 0.6 & 0.6 & 0.3 \\
\hline $\mathrm{Gd}$ & 3.0 & 2.7 & 2.6 & 1.6 & 1.7 & 1.6 & 2.4 & 2.3 & 2.2 & 3.4 & 2.6 & 1.0 \\
\hline $\mathrm{Tb}$ & 0.5 & 0.5 & 0.5 & 0.3 & 0.3 & 0.3 & 0.5 & 0.4 & 0.4 & 0.2 & 0.3 & 0.1 \\
\hline Dy & 3.3 & 3.2 & 3.1 & 2.3 & 2.3 & 2.3 & 3.1 & 2.9 & 2.8 & 0.9 & 1.5 & 0.6 \\
\hline $\mathrm{Ho}$ & 0.7 & 0.7 & 0.7 & 0.5 & 0.5 & 0.5 & 0.6 & 0.6 & 0.6 & 0.1 & 0.3 & 0.1 \\
\hline $\mathrm{Er}$ & 1.9 & 1.9 & 2.0 & 1.3 & 1.4 & 1.4 & 1.8 & 1.7 & 1.6 & 0.3 & 0.7 & 0.2 \\
\hline $\mathrm{Tm}$ & 0.3 & 0.3 & 0.3 & 0.2 & 0.2 & 0.2 & 0.3 & 0.2 & 0.2 & 0.0 & 0.1 & 0.0 \\
\hline $\mathrm{Yb}$ & 1.8 & 1.9 & 2.0 & 1.3 & 1.5 & 1.4 & 1.7 & 1.6 & 1.6 & 0.2 & 0.7 & 0.2 \\
\hline Lu & 0.3 & 0.3 & 0.3 & 0.2 & 0.2 & 0.2 & 0.3 & 0.3 & 0.3 & 0.0 & 0.1 & 0.0 \\
\hline $\mathrm{Hf}$ & 1.0 & 0.6 & 0.6 & 0.4 & 0.5 & 0.6 & 0.7 & 0.6 & 0.6 & 3.8 & 3.3 & 1.5 \\
\hline Ta & 0.2 & 0.1 & 0.1 & 0.1 & 0.1 & 0.1 & 0.1 & 0.1 & 0.1 & 0.5 & 1.1 & 1.9 \\
\hline $\mathrm{Pb}$ & 1.4 & 1.5 & 1.1 & 1.3 & 0.8 & 0.5 & 0.6 & 1.3 & 1.2 & 9.5 & 7.6 & 7.4 \\
\hline $\mathrm{Th}$ & 0.4 & 0.2 & 0.2 & 0.2 & 0.2 & 0.1 & 0.3 & 0.3 & 0.2 & 10.1 & 4.2 & 0.9 \\
\hline$U$ & 0.1 & 0.1 & 0.1 & 0.1 & 0.1 & 0.0 & 0.2 & 0.1 & 0.0 & 0.5 & 0.9 & 0.4 \\
\hline Total REE & 34 & 28 & 29 & 20 & 20 & 20 & 32 & 28 & 26 & 140 & 85 & 20 \\
\hline
\end{tabular}

Major elements (in wt\%) by XRF at GEUS.Trace elements (in ppm) by IC P-MS at GEUS.

$\mathrm{FeO} *$ total Fe calculated as FeO .Volatiles $=$ loss on ignition corrected for oxygen uptake due to oxidation of iron. 
Table 4b. C hemical analyses of vario us supracrustal rocks

\begin{tabular}{|c|c|c|c|c|c|c|c|c|c|}
\hline & 440910 & 440931 & 467503 & 467404 & 467408 & 467417 & 467420 & 467423 & 467433 \\
\hline $\mathrm{SiO}_{2}$ & 63.27 & 69.36 & 74.26 & 62.76 & 61.37 & 59.87 & 75.29 & 49.25 & 49.94 \\
\hline $\mathrm{TiO}_{2}$ & 0.59 & 0.49 & 0.03 & 0.61 & 0.67 & 0.64 & 0.34 & 0.61 & 0.78 \\
\hline $\mathrm{Al}_{2} \mathrm{O}_{3}$ & 17.61 & 16.08 & 14.81 & 19.09 & 13.90 & 16.78 & 13.01 & 16.21 & 15.53 \\
\hline $\mathrm{Fe}_{2} \mathrm{O}_{3}$ & 5.19 & 2.38 & 0.01 & 1.17 & 1.32 & 1.25 & 0.51 & 3.63 & 1.80 \\
\hline $\mathrm{FeO}$ & 0.00 & 0.00 & 0.37 & 5.82 & 6.73 & 5.38 & 1.26 & 6.97 & 8.34 \\
\hline $\mathrm{FeO} *$ & 4.67 & 2.14 & 0.38 & 6.87 & 7.92 & 6.50 & 1.72 & 10.24 & 9.96 \\
\hline $\mathrm{MnO}$ & 0.05 & 0.01 & 0.00 & 0.05 & 0.11 & 0.15 & 0.01 & 0.19 & 0.16 \\
\hline MgO & 2.31 & 1.03 & 0.10 & 2.80 & 6.41 & 3.97 & 0.57 & 7.70 & 7.78 \\
\hline $\mathrm{CaO}$ & 2.26 & 3.17 & 2.02 & 0.75 & 4.60 & 3.68 & 5.62 & 9.21 & 10.73 \\
\hline $\mathrm{Na}_{2} \mathrm{O}$ & 3.84 & 3.85 & 4.89 & 1.60 & 1.82 & 2.73 & 1.05 & 2.63 & 1.88 \\
\hline $\mathrm{K}_{2} \mathrm{O}$ & 3.02 & 1.79 & 2.81 & 3.20 & 1.46 & 3.21 & 0.62 & 1.63 & 0.50 \\
\hline $\mathrm{P}_{2} \mathrm{O}_{5}$ & 0.13 & 0.11 & 0.02 & 0.03 & 0.07 & 0.08 & 0.05 & 0.13 & 0.16 \\
\hline Volatiles & 1.00 & 0.75 & 0.29 & 1.64 & 1.26 & 1.28 & 0.90 & 1.39 & 1.48 \\
\hline Sum & 99.27 & 99.02 & 99.62 & 99.52 & 99.71 & 99.01 & 99.23 & 99.55 & 99.06 \\
\hline Sc & 18.0 & 10.2 & 0.8 & 17.6 & 39.3 & 26.6 & 7.7 & 43.8 & 39.7 \\
\hline V & 98.5 & 38.2 & 1.7 & 56.7 & 208 & 149 & 43.5 & 204 & 209 \\
\hline $\mathrm{Cr}$ & 89.1 & 25.0 & 0.4 & 120.0 & 667 & 312 & 66.1 & 268 & 318 \\
\hline $\mathrm{CO}$ & 22.3 & 17.2 & 26.9 & 16.3 & 44.8 & 28.4 & 14.0 & 51.2 & 50.7 \\
\hline $\mathrm{Ni}$ & 32.3 & 5.2 & 1.3 & 54.7 & 194.0 & 106.0 & 34.0 & 148.0 & 145.0 \\
\hline $\mathrm{Cu}$ & 21.9 & 8.8 & 5.2 & 4.8 & 20.0 & 26.3 & 26.9 & 25.1 & 34.8 \\
\hline Zn & 71.4 & 38.9 & 4.4 & 37.8 & 89.5 & 104.5 & 41.4 & 81.8 & 87.4 \\
\hline $\mathrm{Ga}$ & 20.8 & 19.6 & 16.0 & 25.7 & 17.5 & 23.1 & 15.5 & 16.3 & 15.9 \\
\hline $\mathrm{Rb}$ & 82.7 & 48.2 & 58.5 & 96.9 & 51.1 & 197.0 & 41.6 & 59.1 & 8.0 \\
\hline $\mathrm{Sr}$ & 210 & 314 & 402 & 47 & 117 & 177 & 137 & 270 & 288 \\
\hline Y & 16.0 & 6.4 & 2.4 & 11.1 & 15.4 & 16.7 & 11.1 & 17.4 & 17.0 \\
\hline $\mathrm{Zr}$ & 134 & 151 & 70.8 & 57.7 & 82.4 & 83.1 & 73.9 & 38.4 & 24.0 \\
\hline $\mathrm{Nb}$ & 5.6 & 5.6 & 0.8 & 8.7 & 3.3 & 6.9 & 2.9 & 2.3 & 2.0 \\
\hline Cs & 4.1 & 4.7 & 0.5 & 2.0 & 2.5 & 8.1 & 2.7 & 2.4 & 0.0 \\
\hline $\mathrm{Ba}$ & 417 & 286 & 591 & 581 & 386 & 377 & 310 & 153 & 97 \\
\hline La & 28.2 & 20.0 & 7.9 & 34.5 & 11.0 & 9.6 & 28.3 & 11.9 & 13.4 \\
\hline $\mathrm{Ce}$ & 58.3 & 40.6 & 16.1 & 64.7 & 29.1 & 28.5 & 56.0 & 29.5 & 37.5 \\
\hline $\mathrm{Pr}$ & 6.9 & 4.4 & 2.1 & 7.4 & 2.9 & 2.6 & 6.5 & 3.8 & 4.5 \\
\hline $\mathrm{Nd}$ & 25.3 & 15.7 & 7.7 & 26.4 & 11.8 & 10.5 & 24.5 & 16.8 & 19.7 \\
\hline $\mathrm{Sm}$ & 4.3 & 2.6 & 1.8 & 4.4 & 2.7 & 2.5 & 4.0 & 3.9 & 4.4 \\
\hline Eu & 1.2 & 0.7 & 0.4 & 0.7 & 0.7 & 0.7 & 1.0 & 1.2 & 1.1 \\
\hline $\mathrm{Gd}$ & 4.5 & 2.6 & 1.5 & 5.0 & 3.6 & 2.3 & 3.9 & 3.5 & 3.8 \\
\hline $\mathrm{Tb}$ & 0.6 & 0.3 & 0.2 & 0.5 & 0.5 & 0.4 & 0.4 & 0.5 & 0.5 \\
\hline Dy & 3.0 & 1.4 & 0.6 & 2.4 & 2.8 & 2.4 & 2.3 & 2.9 & 3.0 \\
\hline $\mathrm{HO}$ & 0.6 & 0.2 & 0.1 & 0.4 & 0.6 & 0.6 & 0.4 & 0.6 & 0.6 \\
\hline $\mathrm{Er}$ & 1.6 & 0.6 & 0.2 & 1.1 & 1.6 & 1.9 & 1.1 & 1.7 & 1.7 \\
\hline Tm & 0.2 & 0.1 & 0.0 & 0.1 & 0.2 & 0.3 & 0.1 & 0.3 & 0.3 \\
\hline$Y b$ & 1.5 & 0.5 & 0.2 & 0.9 & 1.5 & 2.1 & 0.8 & 1.6 & 1.6 \\
\hline Lu & 0.2 & 0.1 & 0.0 & 0.1 & 0.2 & 0.3 & 0.1 & 0.2 & 0.2 \\
\hline $\mathrm{Hf}$ & 3.7 & 3.9 & 2.8 & 1.5 & 2.2 & 2.2 & 1.8 & 1.0 & 0.8 \\
\hline Тa & 0.9 & 2.6 & 1.9 & 0.6 & 0.3 & 0.6 & 0.2 & 0.1 & 0.1 \\
\hline $\mathrm{Pb}$ & 12.7 & 5.2 & 11.8 & 3.7 & 4.7 & 9.5 & 6.1 & 6.6 & 4.2 \\
\hline Th & 6.2 & 3.3 & 4.8 & 8.5 & 3.5 & 6.0 & 4.2 & 2.0 & 2.0 \\
\hline U & 1.5 & 0.9 & 1.3 & 0.8 & 0.9 & 3.1 & 0.9 & 0.7 & 0.6 \\
\hline Total REE & 137 & 90 & 39 & 149 & 69 & 65 & 129 & 79 & 92 \\
\hline
\end{tabular}

Major elements (in wt\%) by XRF at GEUS.Trace elements (in ppm) by ICP-MS at GEUS. Volatiles: loss on ignition corrected for oxygen uptake due to oxidation of iron.

$\mathrm{FeO} *$ : total Fe calculated as $\mathrm{FeO}$. 


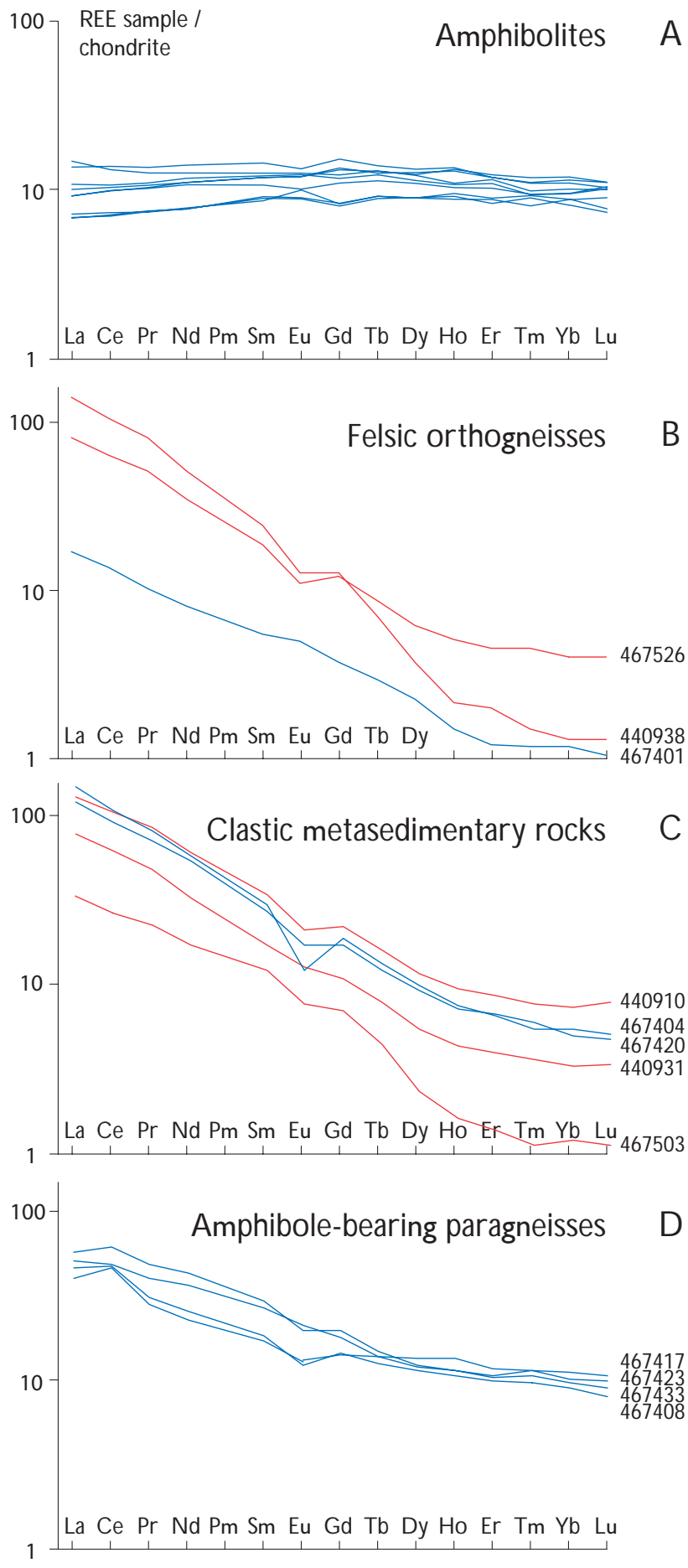

Fig. 8. Chondrite-normalised REE plots. A: amphibolites. B: felsic orthogneiss. C: quartzo-feldspathic metasedimentary rocks. D : mafic metasedimentary rocks. Blue: Samples from the Kangilinaaq region. Red: Samples from the l kamiut region. sample 467423. Sample 467408 has an intermediate silica content ( $61.37 \mathrm{wt} \% \mathrm{SiO}_{2}$ ), is cummingtonite-bearing, and has high concentrations of $\mathrm{M} \mathrm{gO}(6.41 \mathrm{wt} \%)$ and $\mathrm{FeO}$ * (7.92 wt\%) as well as Cr and N (627 and 186 ppm, respectively). It also has high $\mathrm{Ba}$ (405 ppm). The REE curve is almost flat, with ten times chondritic $H$ REE and a weak LREE enrichment $\left(L a_{N} / L u_{N}=5\right)$. There is a small positive $C$ e anomaly in addition to a negative $\mathrm{Eu}$ anomaly.

Metasedimentary rocks from the Ikamiut belt Sample 440910 is the most aluminous (18 wt $\% \mathrm{Al}_{2} \mathrm{O}_{3^{\prime}}$ Table 4), has high REE concentrations, and a fairly steep REE curve with $L a_{N} / L u_{N}=15$ (Fig. 8C). Samples 440931 and 467503 are more siliceous (69 and 74 wt $\% \mathrm{SiO}_{2}$, re spectively) with lower Al, Fe and $\mathrm{M}$ g. Both have lower REE concentrations and slightly steeper REE curves than sample 440910.

\section{Interpretation}

The metasedimentary rocks and amphibole-bearing gneisses of supracrustal origin described above from the Ikamiut and Kangilinaaq belts can be divided into two groups based on their geochemical compositions and REE patterns. Five of them, namely all three I kamiut samples and samples 467404 and 467420 from Kangilinaaq, are typical metasedimentary lithologies with steep REE curves (Fig. 8C). Although they have varying REE concentrations, all five samples have fairly steep REE curves that are comparable to the REE patterns seen in the Kangilinaaq and I kamiut orthogneisses. Thegroup shows a trend of increasing REE concentrations with decreasing $\mathrm{SiO}_{2}$ and increasing $\mathrm{Al}_{2} \mathrm{O}_{3}$, consistent with the general presumption that the REE are preferentially concentrated in the clay fraction of sediments. O ne exception from this is the siliceous sample 467420 that has REE concentrations comparable to the most aluminous metasediments. Its unusual REE enrichment may be due to high contents of detrital allanite and zircon, as these minerals incorporate high REE concentrations.

TheREE curves for the four amphibole-bearing gneisses (467408, 467417, 467423, and 467433; Fig. 8D) have $\mathrm{La}_{N} / \mathrm{Lu}_{\mathrm{N}} \sim 5$, showing significantly flatter patterns. These four samples all have high concentrations of mafic minerals and may represent intermediate tuffaceous rocks or mildly chemically al tered mafic volcanic rocks. The rather peculiar composition of sample 467408, with high $\mathrm{Ni}$ and $\mathrm{Cr}$, suggests that it is a metamorphosed, hydrothermally 


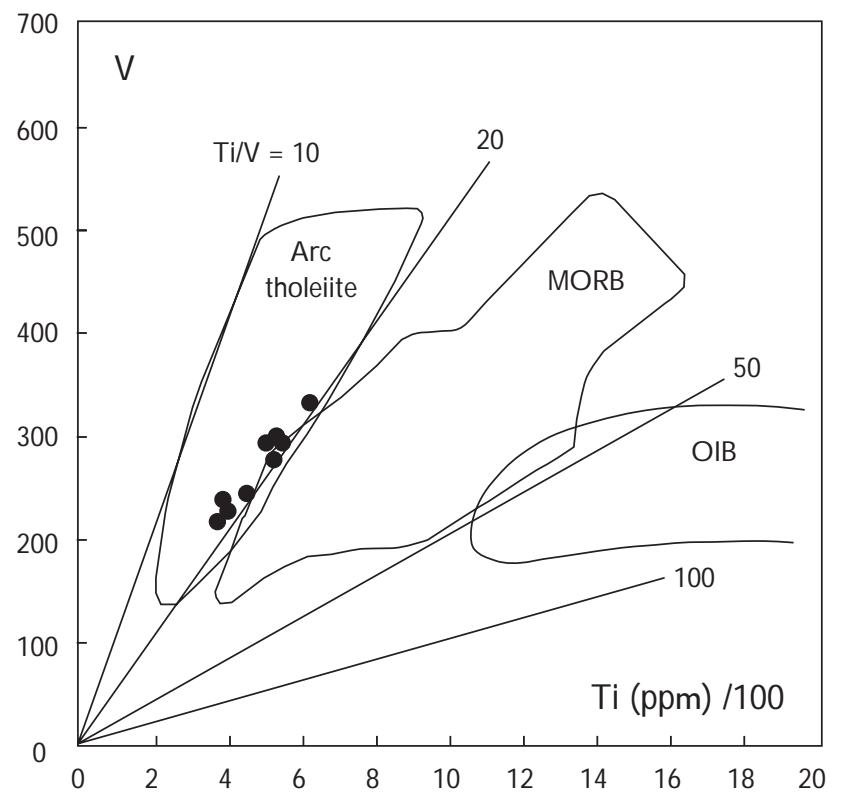

Fig. 9. Ti/V discrimination diagram (Shervais 1982) for nine amphibolite samples from the Kangilinaaq peninsula (Fig. 2B), illustrating their island arc affinities. $\mathrm{N}$ ote that $\mathrm{Ti}$ and $\mathrm{V}$ are both immobile ele ments, considered to be stable during hydrothermal alteration and regional metamorphism (e.g. N icollet \& Andriambololona 1980; M ottl 1983). The partition coefficient of $V$ varies with the oxygen fugacity of the magma, whereas the partition coefficient of $\mathrm{Ti}$ remains unchanged.

altered mafic volcanic rock. Alternatively, such high $\mathrm{Ni}$ and $\mathrm{C}$ rin a clasticsedimentary precursor would require an abundance of heavy minerals such as garnet and spinel.

\section{Discussion}

\section{Regional structures}

Both the Ikamiut and Kangilinaaq regions preserve complex tectono-metamorphic histories, and although they show similarities in lithologies and metamorphic grade (amphibolite facies mineral assemblages defining $D_{1}$ and $D_{2}$ structures) and lie roughly along strike, the largestructures are sufficiently different to make a direct correlation between the two regions and their supracrustal belts difficult and dubious. Both regions show evidence for at least two generations of fold structures, with kilometre to ten kilometre-scale $F_{2}$ folds dominating the outcrop pattern. $\mathrm{H}$ owever, thereis considerablevariation in thetypical strike of foliation and plunge of large-scale folds and lineations between the two regions. Furthermore, the aeromagnetic data do not suggest a strong link between thetwo regions.
O $n$ the basis of geological mapping and the aeromagnetic data it seems likely that the Kangilinaaq belt forms a synformal fold closure at the south-western tip of the Kangilinaaq peninsula, with little or no westward continuation. We cannot rule out the possibility that there is continuation of this belt across Sydostbugten into the Ikamiut region along an abrupt change in the aeromagnetic responseacrossnorthern Sydostbugten (boundary 0 inFig. 3). This could be interpreted as an extension of the linear aeromagnetic anomaly marking the northern contact of the $Q$ asigiannguit amphibolite sequence with the surrounding orthogneiss, which appears to extend westward to several kilometres north of the N ivaap Paa bay (boundary $P$ in Fig. 3). H owever, there is no strong field evidence to support this, sinceno comparable amphibolite sequence occurs on land at Q (Fig. 3). It is possible that this linear aeromagnetic anomaly relates instead to an interpreted granitic body beneath Sydostbugten, represented by outcrop on the south-eastern tip of the K angilinaaq peninsula, and on the south-west coast of N ivaap Paa.

\section{Magmatism}

Geochronological data show that the magmatic precursors to granodioritic orthogneiss from the lkamiut region wereemplaced in the LateArchaean. Sample440938, with a LA-ICP-M S Pb-Pb zircon age of $2831 \pm 23 \mathrm{M} \mathrm{a} \mathrm{U}-\mathrm{Pb}$ zircon ages of 2820-2810 M a, is significantly older than sample 467526, which was collected from a nearby locality (LA-ICP-M S Pb-Pb zircon age $=2741 \pm 53 \mathrm{M}$ a). The latter compares well with a homogeneous undeformed granite collected a few kilometres west of the head of $\mathrm{N}$ ivaap Paa, which yielded an upper intercept $\mathrm{U}-\mathrm{Pb}$ zircon age of $2778+7 /-3 \mathrm{M}$ a (Connelly $\&$ M engel 2000). Similarly, a grey tonalitic orthogneiss sampled close to Aasiaat yielded a U -Pb concordia age of $2727+36 /-22$ $\mathrm{M} \mathrm{a}$ and consistent $\mathrm{Pb}-\mathrm{Pb}$ and $\mathrm{Rb}-\mathrm{Sr}$ whole-rock ages of $2759+87 /-92 \mathrm{M}$ a and $2752 \pm 656 \mathrm{M}$ a respectively (Kalsbeek et al. 1987).

Available data on emplacement ages of the precursors to thetonalitic orthogneiss in the K angilinaaq region suggest these may be slightly older than those in the I kamiut region. Kalsbeek \& N utman (1996) reported ion probe data for a few zircon grains from a granodioritic to granitic orthogneiss in the Kangilinaaq area, which gave an emplacement age between 2900 and $2750 \mathrm{M}$ a. Keiding (2004) presented LA-ICP-M S ${ }^{207} \mathrm{~Pb} /{ }^{206} \mathrm{~Pb}$ zircon age data for a tonalitic orthogneiss of $2818 \pm 1 \mathrm{M}$ a, interpreted as an igneous crystallisation age. 


\section{Sedimentation}

D eposition of the sedimentary precursors to the I kamiut and Kangilinaaq belts likely occurred in the N eoarchaean, as indicated by the metamorphic ages of c. 2800-2700 $\mathrm{M}$ a of zircon from both belts. The age of the Kangilinaaq belt is further constrained by the $2723 \pm 15 \mathrm{M}$ a emplacement age of a two-mica granite, which cross-cuts pelitic metasedimentary rocks of this belt on the south shore of Kangersuneq fjord (Thrane \& Connelly 2006, this volume). As regards the I kamiut belt, its detrital zircon ages do not preclude deposition after the Archaean. Neoarchaean metamorphic rims have been observed on some detrital grains, but these might have formed al ready during metamorphism of the source and survived during erosion and deposition. However, we consider this possibility unlikely. A N eoarchaean depositional age is furthermore in agreement with the Rb-Sr isotopic data for 12 metasedimentary samples from Ikamiut reported by K alsbeek \& Taylor (1999), which likewise show that their source was Archaean. Finally, the I kamiut belt has experienced a more complex structural history than the $\mathrm{N}$ aternaq supracrustal belt of Palaeoproterozoic age to its south (Ø stergaard et al. 2002; G arde 2004; T hrane \& Connelly 2006, this volume). This likewise points to an Archaean age of the Ikamiut belt.

The depositional sources themselves are constrained by detrital zircon populations. The detrital age spectrum for zircon grains (with igneous zonation) from metasedimentary sample 440910 from the l kamiut region forms a tightly clustered peak at c. $2800 \mathrm{M}$ a, consistent with the age of the older tonalitic orthogneiss in this area. Furthermore, the steep REE pattern of this sample mimics that of the granodioritic to tonalitic orthogneiss that dominates the region. Thus the sedimentary precursor to this rock was probably derived locally from (and possibly deposited onto) theigneous precursor to the $\mathrm{N}$ eoarchaean orthogneiss basement. This requires a tectonic environment conduciveto rapid erosion of theprecursor to thesource orthogneiss shortly after its emplacement at c. $2800 \mathrm{M} \mathrm{a}$.

Similarly, a metasedimentary rock from theK angilinaaq region contains Archaean detrital zircon, with a strong peak at C. $2800 \mathrm{M} \mathrm{a}$ (Thrane \& Connelly 2006, this vol-

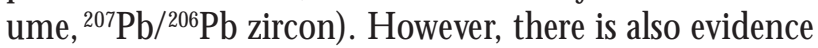
for a significant older component, not recognised in metasedimentary rocks from the Ikamiut region: Keiding (2004) reported detrital zircon agesfor two metasedimentary samples from the Kangilinaaq region with grains as old as $3600 \mathrm{M} \mathrm{a}$, and down to $2500 \mathrm{M} \mathrm{a}$, although the youngest grains $(<2800 \mathrm{M}$ a) were suspected of having suffered lead loss. Both samples show a large spread of ages, but neither has a significant $\mathrm{N}$ eoarchaean component at c. $2800 \mathrm{Ma}$. These data contrast with those of sample 440910 from the lkamiut region, which hasatightly clustered detrital zircon population at c. $2800 \mathrm{M}$ a. This suggests that at least some of the Kangilinaaq metasedimentary rocks were derived from different, older, and distal source rocks: the older (>2900 M a) component may be derived from a presently unexposed region within the $N$ agssugtogidian orogen or possibly from the lesser-known craton to the north (Keiding 2004).

A difference in the depositional sources of the lkamiut and K angilinaaq belts is also apparent from the geochemical data. The metasedimentary rocks form two groups based on their REE patterns. The first group (three Ikamiut and two Kangilinaaq samples) shows steep REE curves (Fig. $8 \mathrm{C}$ ), interpreted as indicative of derivation from a felsic source, based on their similarity with REE patterns seen in the Kangilinaaq and I kamiut orthogneisses. The second group (four K angilinaaq samples, Fig. 8D ) shows flatter patterns, consistent with derivation from a bimodal source, i.e. detritus of both felsic (steep REE patterns) and mafic (flat REE patterns) igneous rocks. The precursors to the amphibole bearing gneisses are interpre ted as volcaniclastic material that may have been mixed with clastic material during deposition or by tectonic interleaving. Given the intensity of deformation and paucity of information on the depositional environment(s) we consider it imprudent to establish a single stratigraphicstructural interpretation. In view of the different dominant lithologies of the $Q$ asigiannguit amphibolite and the remainder of the Kangilinaaq belt, it would be interesting to investigate further whether they rep resent the same or different settings. The geochemistry of their amphibolite samples fall within the same range, but no metasedimentary rocks associated with the $Q$ asigiannguit amphibolite have been analysed, and these may be important for identifying links between the latter unit and the Kangilinaaq belt.

\section{Metamorphism}

Age data for metamorphic zircon from orthogneiss and metasedimentary samples from the I kamiut region indicate an important $\mathrm{N}$ eoarchaean thermal event. Two analyses of metamorphic rims from the $2831 \pm 23 \mathrm{M}$ a orthogneiss 440938 yield ages of $2761 \pm 10 \mathrm{M}$ a and $2754 \pm 5$ $M$ a, within error the same as the $2741 \pm 53 \mathrm{M}$ a emplace ment age of sample 467526 (Fig. 7). This may suggest that continued synkinematic emplacement of $\mathrm{N}$ eoarchaean granitoids at c. 2760-2700 M a resulted in metamorphism 
of slightly older (c. $2800 \mathrm{M}$ a) crust. This is also supported by $\mathrm{U}-\mathrm{Pb}$ zircon data from the metasedimentary sample 440910. The six SI M S ages of metamorphic rims fall in two ranges, $2741 \pm 9 \mathrm{M}$ aand $2696 \pm 6 \mathrm{M}$ a, and similar young ages were identified in the LA-ICP-M S data (Fig. 7). These ages probably relate to the growth of $S_{1}$ garnet, biotite, plagioclase, quartz, minor sillimanite and $\mathrm{K}$-feldspar in this and other metasedimentary rocks, indicative of amphibolite facies conditions only shortly after deposition, and predating regional $\mathrm{F}_{2}$ folding. $\mathrm{N}$ eoarchaean metamorphism has also been recognised from zircon age data in the Kangilinaaq region. Keiding (2004) reported c. 2800 and 2760 $\mathrm{M}$ a LA-ICP-M S ages of zircon rims and discrete grains, interpreted as metamorphic in origin, in a $2818 \pm 1 \mathrm{M} \mathrm{a}$ tonalitic orthogneiss. These ages correlate reasonably well with 2810-2720 M a metamorphic U - Pb zircon and monaziteages in 2870-2810 M a orthogneisses from throughout the $\mathrm{N}$ agssugtoqidian orogen ( $\mathrm{C}$ onnelly \& M engel 2000).

It is likely that Neoarchaean amphibolite facies metamorphism in the Ikamiut and Kangilinaaq regions was the product of tectonism along a convergent margin (see also Connelly \& Mengel 2000) on the basis of (1) the tonalitic to granodioritic composition of the N eoarchaean regional orthogneisses, (2) the apparent island arc geochemical character of amphibolites of the Kangilinaaq belt, (3) differences in the ages of sediment sources in the two supracrustal belts, and (4) the rapidity of the cycle of magmatism, erosion, sedimentation, and metamorphism.

Proterozoic zircon ages are known from the Kangilinaaq region. Keiding (2004) reported 1920-1820 M a LAICP-M S ages of zircon rims and discrete grains in Archaean tonalitic orthogneisses, and also reported weighted mean age of $1919 \pm 11 \mathrm{M}$ a from three rims of detrital grains in a metasedimentary rock from the Kangilinaaq belt. Thrane\& Connelly (2006, this volume) report metamorphic ages of c. $1850 \mathrm{M}$ a for a metasedimentary rock collected on the south shore of Kangersuneq fjord, attributed to the peak of regional N agssugtogidian metamorphism. Given the consistency of EN E-trending D structures in the Kangilinaaq and I kamiut regions with EN Etrending Pal aeoproterozoic structures throughout the orogen, these are interpreted as the product of the c. 1850 $\mathrm{M}$ a N agssugtogidian orogenesis. The significance of the slightly older, c. $1920 \mathrm{M}$ a metamorphic age is not clear, but may indicate that part of this region experienced a thermal event prior to themain regional $\mathrm{N}$ agssugtogidian orogenesis.

By contrast, no significant indications of Palaeoproterozoic resetting are found in our I kamiut data. The slightly discordant zircon data in sample 440938 suggest some
$\mathrm{Pb}$ loss in this sample, although the timing is not clear. Similarly, three titanite U $-\mathrm{Pb}$ analyses of $2778+7 /-3 \mathrm{M}$ a reported by Connelly \& M engel (2000) from a homogeneous, undeformed granite plot on a discordialine between $2789 \pm 100$ and $1775 \pm 10 \mathrm{M}$ a. This indicates that Palaeoproterozoic metamorphic temperatures were too low to completely reset titanite in this region. Likewise, no indication of $\mathrm{U}-\mathrm{Pb}$ resetting in zircon was found in the 2727 $+36 /-22 \mathrm{M}$ a age from a tonalitic gneiss reported by Kalsbeek et al. (1987). T his contrasts with zircon U -Pb analyses of samples from the N ordre Strømfjord region in the core of the $\mathrm{N}$ agssugtogidian orogen, which experienced significant Pb-loss at c. $1850 \mathrm{M} \mathrm{a}$ (Kalsbeek et al. 1987).

\section{Conclusions}

$\mathrm{N}$ ew mapping, geochemical, geochronological and geophysical studies of two supracrustal belts from Sydostbugten, southern D isko Bugt region, West G reenland, shed light on the $\mathrm{N}$ eoarchaean tectonic evolution of the northern $\mathrm{N}$ agssugtogidian basement. TheK angilinaaq belt was deposited at c. $2800 \mathrm{Ma}$, whereas the deposition of the I kamiut belt may postdatec. $2740 \mathrm{M}$ a. The geochemical signatures of the majority of metasedimentary samples from the Kangilinaaq region show REE patterns indicative of mixed felsic and mafic sources with distal M esoand Palaeoarchaean components that are not currently known in situ in this part of West Greenland. Island-arc geochemical affinities of intercalated amphibolites are consistent with deposition in an arc setting. In contrast, the I kamiut belt was sourced locally from, and deposited onto or proximal to theigneous precursors of $\mathrm{N}$ eoarchaean granodioritic to tonalitic orthogneisses. This is constrained by (1) the similarity in REE signatures of metasedimentary rocks and local orthogneisses and (2) the zircon emplacement ages of orthogneisses (c. 2820-2810 M a; 2831 $\pm 23 \mathrm{M} \mathrm{a} ; 2741 \pm 53 \mathrm{M}$ a) and detrital zircons in metasediment $(2779 \pm 18 \mathrm{M}$ a).

Zircon U-Pb data and $\mathrm{S}_{1-2}$ sillimanite-bearing mineral assemblages (this study and existing data) indicate that $c$. 2800-2700 M a amphibolitefacies metamorphism affected both regions, shortly after the emplacement of the regional orthogneiss precursors and deposition of the supracrustal rocks. The rather rapid cycle of magmatic emplacement, island arc volcanism, erosion and sedimentation, and subsequent amphibolite facies metamorphism is consistent with $\mathrm{N}$ eoarchaean convergent tectonism at the northern margin of the present $\mathrm{N}$ agssugtogidian orogen.

Subsequently, both regions underwent Palaeoproterozoic regional deformation and lower amphibolite facies 
metamorphism at c. $1850 \mathrm{M}$ a during the $\mathrm{N}$ agssugtogidian orogenesis, the effects of which control outcrop patterns in both areas. In the l kamiut region, the supracrustal belt defines a broad, shallowly W -plunging antiformal structure with associated kilometre-scale parasitic $\mathrm{F}_{2}$ folds. $\mathrm{S}_{1}$ fabrics are folded into metre to kilometre-scale $F_{2}$ folds and variably transposed into EN E-striking, steeply dipping $\mathrm{S}_{2}$ fabrics and shallow W -plunging mineral lineations defined by biotite and muscovite.

In the Kangilinaaq region, the supracrustal belt defines a broad, $N$ E-plunging $F_{2}$ fold structure. A pervasive, $N E$ striking, moderately dipping $\mathrm{S}_{2}$ fabric, defined by mediumto coarse-grained garnet-hornblende-biotite-sillimanitebearing assemblages in pelitic rocks, is folded into $\mathrm{F}_{3}$ folds, and attests to amphibolitefacies metamorphic conditions during deformation. Lack of Palaeoproterozoic resetting of the zircon $\mathrm{U}-\mathrm{Pb}$ isotopic system in the l kamiut region, cf. the Kangilinaaq region, suggests that temperatures were relatively lower in the former region during the $\mathrm{N}$ agssugtogidian orogenesis.

\section{Acknowledgements}

$M$ ads Sylvest C hristensen, Jane Gilotti, C hristian Knudsen, Stanislaw M azur, M ac Persson, Sandra Piazolo and Thomas V. Rasmussen contributed to field work in 20022003 reported here and part of the G EUS project Archaean and Proterozoic crustal evolution in the Aasiaat region, central West Greenland. Dirk Frei, M ark T. H utchison, Lev Ilyinsky, Jørgen Kystol, Ingerlise N ørgaard, T homas V. Rasmussen, M ikkel Vognsen, and $M$ artin W hitehouse provided support and assistancein sample preparation and collection of analytical data. The $\mathrm{N}$ ordsim laboratory is funded and operated under agreement between the research funding agencies of D enmark, N orway, and Swe den, GTK, Finland, and Naturhistoriska Riksmuseet, Sweden; this is Nordsim contribution no. 164. Clark Friend, Lotte M elchoir Larsen and an anonymous reviewer are thanked for critical reviews.

\section{References}

Connelly, J.N . \& Mengel, F.C. 2000: Evolution of Archean components in thePaleoproterozoic N agssugtoqidian orogen, W est Greenland. G eological Society of America Bulletin 112, 747-763.

Connelly, J.N ., van Gool, J.A.M . \& M engel, F.C. 2000:Temporal evolution of a deeply eroded orogen: the $N$ agssugtogidian orogen, West Greenland. Canadian J ournal of Earth Sciences 37, 1121-1142.

Garde, A.A. 2004: Geological map of Greenland, 1:100 000, Kangaat- siaq, 68 V.1 Syd. Copenhagen: G eological Survey of D enmark and Greenland.

Garde, A.A. in press: Geological map of Greenland, 1:100 000, Ikamiut, 68 V.1 Nord. Copenhagen: Geological Survey of D enmark and $\mathrm{G}$ reenland.

Garde, A.A. \& Steenfelt, A. 1999: Precambrian geology of N uussuaq and the area north-east of D isko Bugt, West G reenland. G eology of Greenland Survey Bulletin 181, 6-40.

Garde, A.A., Christiansen, M.S., H ollis, J.A., M azur, S. \& van Gool, J.A.M . 2004: Low-pressure metamorphism during Archaean crustal growth: a low-strain zone in the northern Nagssugtogidian orogen, West G reenland. G eological Survey of D enmark and Greenland Bulletin 4, 73-76.

H enderson, G. 1969:ThePrecambrian rocks of the Egedesminde-C hristianshåb area (sheets 68V.1 and 68V.2). Rapport Grønlands G eologiske Undersøgelse 23, 1-37.

H ollis, J.A., Garde, A.A., van Gool, J.A.M .\& Thrane K. 2004: Polymetamorphism in the northern $\mathrm{N}$ agssugtogidian orogen: a review and presentation of recent data. D anmarks og Grønlands G eologiske Undersøgelse Rapport 2004/17, 25-27.

Jacobsen, B.H. 1987: A case for upward continuation as a standard separation filter for potential-field maps. Geophysics 52, 1138-1148.

Kalsbeek, F. \& N utman A.P. 1996: Anatomy of the Early Proterozoic Nagssugtoqidian orogen, West Greenland, explored by reconnaissance SH RIM P U -Pb zircon dating. G eology 24, 515-518.

Kalsbeek, F. \& Taylor, P.N . 1999: Review of isotope data for Precambrian rocks from the $D$ isko Bugt region, West Greenland. Geology of Greenland Survey Bulletin 181, 41-47.

Kalsbeek, F., Pidgeon, R.T. \& Taylor, P.N . 1987: N agssugtogidian mobile belt of West Greenland: a cryptic $1850 \mathrm{M}$ a suture between two Archaean continents - chemical and isotopic evidence. Earth and Planetary Science Letters 85, 365-385.

Keiding, M. 2004: Petrologiske og geokronologiske undersigelser af prækambriske bjergarter fra Kangilinaaq, Vestgrønland, 70 pp. U npublished M aster thesis, Københavns U niversitet, D anmark.

Kystol, J. \& Larsen, L.M. 1999: Analytical procedures in the Rock Geochemical Laboratory of the Geological Survey of Denmark and Greenland. Geology of Greenland Survey Bulletin 184, 59-62.

Ludwig, K.R. 2000: Isoplot/Ex version 2.2: a geochronological toolkit for M icrosoft Excel. Berkeley: B erkeley G eochronology Center.

M azur, S., Piazolo, S. \& Alsop, G.I. 2006: Structural analysis of the northern $\mathrm{N}$ agssugtogidian orogen, W est Greenland: an example of complex tectonic patterns in reworked high-grademetamorphic terrains. In: G arde, A.A. \& Kalsbeek, F. (eds): Precambrian crustal evolution and C retaceous-Palaeogene faulting in West Greenland. Geological Survey of D enmark and Greenland Bulletin 11, 163178 (this volume).

M ottl, M .J. 1983: M etabasalts, axial hot springs, and the structure of hydrothermal systems at mid-ocean ridges. Geological Society of America Bulletin 94, 161-180.

Nicollet, C.\& Andriambololona, D.R. 1980: Distribution of transition elements in crustal metabasic igneous rocks. Chemical G eology 28, 79-90.

Nielsen, B.M . \& Rasmussen, T.M . 2004: M ineral resources of the Pre cambrian shield of central W est G reenland $\left(66^{\circ}\right.$ to $\left.70^{\circ} 15^{\prime} \mathrm{N}\right)$. Part 
3. Implications of potential field data for the tectonic framework. D anmarks og G rønlands Geologiske U ndersøgel se R apport 2004/ 21, $165 \mathrm{pp}$.

N oe-N ygaard, A. \& Ramberg, H . 1961: Geological reconnaissancemap of the country between latitudes $69^{\circ} \mathrm{N}$ and $63^{\circ} 45^{\prime} \mathrm{N}$, West Greenland. M eddelelser om Grønland 123, 1-9.

$\varnothing$ stergaard, C., G arde, A.A., N ygaard, J., Blomsterberg, J., N ielsen, B.M ., Stendal, H .\& T homas, C.W. 2002: The Precambrian supracrustal rocks in the $\mathrm{N}$ aternaq (Lersletten) and I kamiut areas, central W est Greenland. Geology of Greenland Survey Bulletin 191, 2432.

Pearce, N .J.G., Perkins, W.T., W estgate, J.A., G orton, M .P., Jackson, S.E., N eal., C.R. \& Cheney, S.P. 1997: A compilation of new and published major and trace element data for NIST SRM 610 and N IST SRM 612 glass reference material. G eostandards N ewsletter 21, 115-144.

Piazolo, S., Alsop, G .I ., N ielsen, B.M . \& van G ool, J.A.M ., 2004: The application of GIS to unravel patterns of deformation in high grade terrains: a case study of indentor tectonics from West $\mathrm{G}$ reenland. In Alsop, G .I \& \& H oldsworth, R.E. (eds): Flow processes in faults and shear zones. Geological Society Special Publication (London) 224, 63-78.

Shervais, J.W. 1982: Ti-V plots and the petrogenesis of modern and ophiolitic lavas. Earth and Planetary Science Letters 59, 101-118.

Taylor, P.N . \& Kalsbeek, F. 1990: D ating the metamorphism of Pre cambrian marbles: examples from Proterozoic mobilebelts in Grenland. Chemical G eology 86, 21-28.

Taylor, S.R. \& M cLennan, S.M . 1985: The continental crust: its composition and evolution, 312 pp. 0 xford: Blackwell Scientific Publications.
Thorning, L. 1993: Project AERO M AG -92: a new high resolution aeromagnetic survey of the Lersletten area, central West Greenland $\left(68^{\circ} 15^{\prime}\right.$ to $68^{\circ} 55^{\prime} \mathrm{N}, 50^{\circ} 25^{\prime}$ to $\left.53^{\circ} 35^{\prime} \mathrm{W}\right)$. O pen File Series G rønlands $\mathrm{G}$ eologiske U ndersøgelse 93/2, $36 \mathrm{pp}$.

Thrane, K. \& Connelly, J.N. 2006: Zircon geochronology from the Kangaatsiaq-Q asigiannguit region, the northern part of the 1.9$1.8 \mathrm{G}$ a N agssugtoqidian orogen, West Greenland. In: Garde, A.A. $\&$ Kalsbeek, F. (eds): Precambrian crustal evolution and CretaceousPalaeogene faulting in West G reenland. G eological Survey of D enmark and Greenland Bulletin 11, 87-99 (this volume).

van Gool, J.A.M. 2005: Geological map of Greenland, 1:100 000, Kangersuneq, 68 V.2 Syd. Copenhagen: G eological Survey of D enmark and Greenland.

van Gool, J.A.M ., Connelly, J.N ., M arker, M . \& M engel, F.C. 2002a: The Nagssugtogidian orogen of West $G$ reenland: tectonic evolution and regional correlations from a West $\mathrm{G}$ reenland perspective. $\mathrm{C}$ anadian Journal of Earth Sciences 39, 665-686.

van Gool, J.A.M . et al. 2002b: Precambrian geology of the northern $\mathrm{N}$ agssugtoqidian orogen, West Greenland: mapping in theK angaatsiaq area. G eology of G reenland Survey Bulletin 191, 13-23.

Whitehouse, M.J., Claesson, S., Sunde, T. \& Vestin, J. 1997: I on microprobe U-Pb zircon geochronology and correlation of Archaean gneissesfrom the L ewisian C omplex of Gruinard Bay, northwestern Scotland. Geochimica et Cosmochimica Acta 61/20, 4429-4438.

W iedenbeck, M., Alle, P., Corfu, F., G riffin, W.L., M eier, M ., Oberli, F., von Q uadt, A., Roddick, J.C. \& Spiegel, W. 1995: Threenatural zircon standards for $\mathrm{U}$-Th-Pb, Lu-H f, trace element and REE analyses. G eostandards N ewsletter 19/1, 1-23. 
